\title{
Temporaliteit en modaliteit
}

\section{Abstract}

This article reviews Binary Tense theory as developed by Verkuyl (2008) on the basis of three oppositions proposed by Te Winkel (1866): present-past, synchronous-posterior and imperfect-perfect. Verkuyl followed Te Winkel in assuming that the verb zullen ('will') can be used as a temporal auxiliary expressing posteriority, but here it will be argued that zullen should be considered a purely modal verb and thus does not contribute to the temporal meaning of the clause. The notion of posteriority is, in fact, an integral part of the meaning of past and present, and can be brought to the fore by the use of temporal adverbs like morgen 'tomorrow' or by pragmatic considerations. The article discusses several proposals in the Dutch linguistic literature in which the modal nature of zullen is recognized, but they fail to be convincing in the absence of a crucial innovation: the rejection of the point of speech $n$ as the present in favor of assuming a present tense domain in which $n$ is a moving point that splits the actualized part of the present from its non-actualized (modal) part.

\section{Introductie}

Voorzover ons bekend, is L.A. te Winkel (1810-1868) de eerste geweest die voorstelde om het Nederlandse tempussysteem te beschrijven in termen van drie binaire opposities:
a. Heden (PRES) vs. Verleden (PAST)
b. Synchroon (SYN) vs. Posterieur (POST)
c. Imperfect (IMP) vs. Perfect (PERF)

Te Winkel (1866) hanteert niet de primaire driedeling Verleden-Heden-Toekomst die gebruikelijk is geworden in de taaltheoretische en logisch-semantische traditie gebaseerd op Reichenbach (1947) en die in zijn tijd ook al bestond in gebruiksgrammatica's en in

* Henk Verkuyl is als emeritus hoogleraar verbonden aan de Universiteit Utrecht (email: H.J.Verkuyl@uu.nl). Hans Broekhuis is als onderzoeker verbonden aan het Meertens instituut te Amsterdam (hans.broekhuis@ meertens.knaw.nl). We willen de gastredactie en de beoordelaars van dit artikel bedanken voor hun commentaar dat ons in staat heeft gesteld onze presentatie op verschillende punten te verhelderen. 
de taalkundige vakliteratuur: Weiland (1805), Bilderdijk (1826), Kollewijn (1892), Den Hertog (1903), om maar enkele Nederlandse driedelers te noemen. Te Winkels keuze voor een binair systeem was toen ook al opvallend. De driedeling sluit als vanzelfsprekend aan op onze intuïties over hoe tijd zich het best laat ordenen op basis van onze dagelijkse ervaringen ermee: we praten over dingen uit het verleden, in het heden en in de toekomst. Desondanks stelt Te Winkel dat de voornaamste indeling van de Nederlandse tempusvormen die is tussen Heden en Verleden, waarmee de rol van het Futurum als tempusvorm secundair wordt.

Verkuyl (2012) is een korte samenvatting van Te Winkels systeem zoals dat formeelsemantisch gemoderniseerd is in Verkuyl (2008). In deze formalisering worden elementen die systematisch bijdragen aan het tempussysteem uitgedrukt door de operatoren die in (1) per oppositie staan vermeld. Voor elk van de zes operatoren geldt dat hij staat vóór een tempusloze zin die we hier steeds met $p$ aanduiden. De eerste oppositie is uitzonderlijk in die zin dat door de toepassing van PRES of PAST op een tempusloze $p$ altijd een zin met een persoonsvorm ontstaat. Dat geldt voor de vier andere niet. We illustreren de werking van het systeem van operatoren met enkele voorbeelden.

Als $p$ staat voor de tempusloze zin Marie wandelen, staat $\operatorname{PERF}(p)$ voor de tempusloze zin Marie hebben gewandeld en $\operatorname{IMP}(p)$ voor Marie wandelen. Daarmee zijn beide geschikt als input voor de operatoren uit oppositie (lb). Volgen we Te Winkel in de tweede oppositie, dan wordt de tempusloze zin Marie zullen wandelen uitgedrukt als $\operatorname{POST}(\operatorname{IMP}(p))$, terwijl SYN $(\operatorname{PERF}(p))$ zou staan voor Marie hebben gewandeld. Dit houdt in dat een zin als Marie zal hebben gewandeld binair te representeren is als $\operatorname{PRES}(\operatorname{POST}(\operatorname{PERF}(p)))$, Marie zou wandelen als $\operatorname{PAST}(\operatorname{POST}(\operatorname{IMP}(p)))$ en Marie heeft gewandeld als $\operatorname{PRES}(\operatorname{SYN}(\operatorname{PERF}(p)))$. Daarmee wordt de persoonsvorm zal principieel op dezelfde wijze behandeld als de persoonsvorm wandelt in Marie wandelt: zal wordt opgevat als gevormd uit PRES+zullen en wandelt als gevormd uit PRES+wandelen.

Te Winkels tweedeling is principieel anders dan de conceptueel zo voor de hand liggende driedeling. Niet alleen moeten door de toepassing van POST zowel Heden als Verleden een toekomst bevatten en zulks op analoge wijze, maar ook dwingt zijn systeem een andere analyse van het begrip 'Heden' af, en daarmee van het begrip 'Verleden'. In ternaire taalkundige analyses valt het begrip 'Heden' - net als in de natuurkundesamen met een voortdurend schuivend moment van een punt, vóór hetwelk het verleden zich bevindt en na hetwelk de toekomst zich voordoet. Dit bewegende Heden wordt in het algemeen dan gezien als het punt van spreken $S$, maar het is dan ook meteen duidelijk dat men iets wegmoffelt. Een ondeelbaar Nu-punt valt immers niet goed te rijmen met de notie van moment van spreken: het uitspreken van een zin neemt meestal aanzienlijk meer tijd in beslag dan wat de strikte notie van punt toestaat. Over dat probleem wordt meestal wat lichtvoetig heen gestapt. Wel wordt in de Reichenbachiaanse praktijk het moment $\mathrm{Nu}$ soms naar het Verleden toe uitgerekt, zodat een interval (Extended Now) ontstaat waarin men in elk geval de tijd van de spreeksituatie kan herbergen. Daarmee blijft de notie van Heden echter duister: is het eigenlijk toch dat vliedende punt of is het een domein waarin gebeurens kunnen worden ondergebracht?

Verkuyl (2008) volgt bij het definiëren van tempusoperatoren een belangrijke aanname van Te Winkel, namelijk dat zullen (ook) een temporeel hulpwerkwoord is. Broekhuis \& Verkuyl (2014) ondergraaft die stelling, nadat de eerste auteur ervan de tweede overtuigd had 
van de voordelen van een louter modale analyse van wat bij Te Winkel nog werd gezien als een temporeel zullen. Die voordelen komen voort uit de mogelijkheid om de semantiek van tempusvormen te ontdoen van elementen die een natuurlijke plaats krijgen in de pragmatiek. Het huidige artikel bespreekt daarom de vraag of (en zo ja, hoe) uit een binaire opbouw van het tempussysteem dwingend kan worden afgeleid dat zullen uitsluitend een modaal werkwoord is. Het antwoord op die vraag is bevestigend. Dit betekent dat de zinnen in (2) die in de meeste contexten naar een nog te maken afspraak verwijzen, temporeel gezien op dezelfde wijze worden behandeld, namelijk als zinnen met een tegenwoordige tijdsvorm.
a. Marie moet een afspraak met hem maken.
b. Marie kan een afspraak met hem maken.
c. Marie zal een afspraak met hem maken.
d. Marie maakt een afspraak met hem.
e. Marie gaat een afspraak met hem maken.

Die behandeling houdt in dat aan de infinitiefvorm van de modale hulpwerkwoorden in (2a) - (2c), inclusief zullen, elke temporaliteit wordt ontzegd: wat er aan toekomst wordt uitgedrukt is uitsluitend toe te schrijven aan de betekenis van de operator PRES. Er is dus niet iets als een temporele gebruikswijze van modale hulpwerkwoorden, ook al komen ze vaak voor in zinnen waarin een verwachting wordt uitgesproken over wat gaat gebeuren. Het feit dat ze complexe tempusvormen als Zij zou/moet/kan gisteren hebben gebeld mogelijk maken en dat ze daarom een rol spelen in de temporele structuur wil niet zeggen dat ze zelf temporele informatie leveren.

Voor de modale analyse van zullen vormen de zinnen in (2d) en (2e) een vergelijkingsbasis. Beide lijken toekomst uit te drukken, maar in het geval van (2d) ligt het niet voor de hand om dit toe te schrijven aan de betekenis van het werkwoord maken. En als men-net als het WNT-aan gaan de betekenis toekent 'voorbereidingen treffen', is ook niet goed in te zien waarom in $(2 \mathrm{e})$ die voorbereidingen per se in de toekomst zouden moeten liggen. Alle zinnen in (2) drukken een tegenwoordige tijd uit en nadat men PRES heeft losgemaakt van de infinitiefvormen van de vijf gegeven werkwoorden is het zaak om precies vast te stellen wat de operator PRES uitdrukt en wat voor rekening van de infinitiefvorm komt.

We veronderstellen dat de lezer kan teruggrijpen op Verkuyl (2012) en we zullen daar derhalve zo min mogelijk uit putten. Wel vatten we af en toe samen wat we in Broekhuis \& Verkuyl (2014) over de niet-temporaliteit van zullen hebben gezegd. In de neerlandistische taalkundige literatuur is veel gediscussieerd over de vraag of zullen als temporeel hulpwerkwoord kan worden beschouwd: o.a. in Den Hertog (1903), Droste (1956; 1958), Ebeling (1962; 2006), Rijpma \& Schuringa (1968), Kirsner (1969), Janssen $(1988 ;$ 1989a), Haeseryn et al. (1997). Wat ook de verdiensten en inzichten van deze bijdragen zijn, bij geen van hen volgt dwingend uit de opbouw van het tempussysteem zelf dat elke temporaliteit uit modale hulpwerkwoorden moet worden geëlimineerd. Het feit dat ze voorkomen in semantische domeinen die meestal na het moment van spreken liggen, houdt niet in dat ze zelf de dragers zijn van toekomstinformatie. 


\section{Heden en Verleden}

\subsection{Van punten naar domeinen}

Te Winkel (1866:68f.) spreekt in zijn karakterisering van de drie opposities in (1) in termen van relaties tussen punten. Bij een strikte puntinterpretatie zou dit voor de drie opposities leiden tot de configuraties in tabel 1.

\begin{tabular}{|l|l|l|l|}
\hline & $\begin{array}{l}\text { verleden/heden } \\
\text { 1. Ik kook }\end{array}$ & $\begin{array}{l}2 \\
\text { (niet-)later }\end{array}$ & $\begin{array}{l}3 \\
(\text { on-) voltooid }\end{array}$ \\
\hline 2. Ik heb gekookt & $\mathrm{i}$ & $\mathrm{i} \approx \mathrm{j}$ & $\mathrm{k} \leqslant \mathrm{j}$ \\
\hline 3. Ik zal koken & $\mathrm{i}$ & $\mathrm{i} \approx \mathrm{j}$ & $\mathrm{k}<\mathrm{j}$ \\
\hline 4. Ik zal hebben gekookt & $\mathrm{i}$ & $\mathrm{i}<\mathrm{j}$ & $\mathrm{k} \leqslant \mathrm{j}$ \\
\hline 5. Ik kookte & $\mathrm{i}^{\prime}<\mathrm{i}$ & $\mathrm{i}<\mathrm{j}$ & $\mathrm{k}<\mathrm{j}$ \\
\hline 6. Ik had gekookt & $\mathrm{i}^{\prime}<\mathrm{i}$ & $\mathrm{i}^{\prime} \approx \mathrm{j}$ & $\mathrm{k} \leqslant \mathrm{j}$ \\
\hline 7. Ik zou koken & $\mathrm{i}^{\prime}<\mathrm{i}$ & $\mathrm{i}^{\prime} \approx \mathrm{j}$ & $\mathrm{k}<\mathrm{j}$ \\
\hline 8. Ik zou hebben gekookt & $\mathrm{i}^{\prime}<\mathrm{i}$ & $\mathrm{i}^{\prime}<\mathrm{j}$ & $\mathrm{k} \leqslant \mathrm{j}$ \\
\hline
\end{tabular}

Tabel 1: Te Winkels puntensysteem

In kolom 1 is er een keuze tussen blijven in het presenspunt $i$ en teruggaan naar een punt $i$ ' in het verleden. Zowel op $i$ als op $i^{\prime}$ meldt zich het punt $j$. Er doen zich dan twee mogelijkheden voor: de operator SYN leidt tot synchroniciteit, in kolom 2 gerepresenteerd door $\approx$; de POST-operator positioneert $j$ na $i$ of $i^{\prime}$ en daarvoor is in kolom 2 het relatieteken $<$ beschikbaar. In kolom 3 doet zich een keuze voor met betrekking tot het punt $k$ dat geassocieerd is met de handeling uitgedrukt door de predicatie. Op punt $j$ kan $k$ voltooid zijn $(<$ in de even rijen) of niet ( $\leqslant$ in de oneven rijen).

In Te Winkel (1866) is $i$ te zien als het spreekmoment $n$ en $i^{\prime}$ als een soort virtueel spreekmoment $n^{\prime}$ in het verleden. Te Winkels systeem komt echter beter tot zijn recht bij een interpretatie in termen van temporele domeinen, omdat het daarmee precies de mogelijkheden krijgt die Te Winkel voor ogen moet hebben gestaan. Volgens Verkuyl (2008) zijn er drie aanpassingen voor nodig. Deze veranderingen zijn zichtbaar gemaakt in Tabel 2.

De belangrijkste aanpassing is dat Te Winkels karakterisering van heden ("alles, zooals het zich laat aanzien op het oogenblik dat men denkt") en voor het verleden ("[alles], zooals het zich liet aanzien op het tijdstip, waarin men zich met zijne gedachten terugverplaatst") veel beter te begrijpen is in termen van domeinen dan van punten. De winst die geboekt wordt, is dat het heden in een gesprekssituatie kan gelden als een domein dat door spreker en hoorder als zodanig wordt gezien, los van wat door de predicatie wordt 
uitgedrukt. Een gesprek bestaat immers uit een reeks van zinnen en de notie van heden kan beter los gezien worden van de hedens van de gebeurens in die zinnen. Het heden van een spreker en hoorder is het domein waarin vliedende punt $n$ zich bevindt. Dit wordt in Tabel 2 weergegeven als: $i \circ n$.

\begin{tabular}{|l|l|l|l|}
\hline & $\begin{array}{l}\text { verleden/heden } \\
\text { 1. Ik kook }\end{array}$ & $\begin{array}{l}2 \\
\text { (niet-)later }\end{array}$ & $\begin{array}{l}3 \\
(\text { on-) voltooid }\end{array}$ \\
\hline 2. Ik heb gekookt & $\mathrm{i} \circ \mathrm{n}$ & $\mathrm{i} \approx \mathrm{j}$ & $\mathrm{k} \leqslant \mathrm{j}$ \\
\hline 3. Ik zal koken & $\mathrm{i} \circ \mathrm{n}$ & $\mathrm{i} \approx \mathrm{j}$ & $\mathrm{k}<\mathrm{j}$ \\
\hline 4. Ik zal hebben gekookt & $\mathrm{i} \circ \mathrm{n}$ & $\mathrm{i}<\mathrm{j}$ & $\mathrm{k} \leqslant \mathrm{j}$ \\
\hline 5. Ik kookte & $\mathrm{i}^{\prime}<\mathrm{i}$ & $\mathrm{i}^{\prime} \approx \mathrm{j}$ & $\mathrm{k} \leqslant \mathrm{j}$ \\
\hline 6. Ik had gekookt & $\mathrm{i}^{\prime}<\mathrm{i}$ & $\mathrm{i}^{\prime} \approx \mathrm{j}$ & $\mathrm{k}<\mathrm{j}$ \\
\hline 7. Ik zou koken & $\mathrm{i}^{\prime}<\mathrm{i}$ & $\mathrm{i}^{\prime}<\mathrm{j}$ & $\mathrm{k} \leqslant \mathrm{j}$ \\
\hline 8. Ik zou hebben gekookt & $\mathrm{i}^{\prime}<\mathrm{i}$ & $\mathrm{i}^{\prime}<\mathrm{j}$ & $\mathrm{k}<\mathrm{j}$ \\
\hline
\end{tabular}

Tabel 2: Te Winkels systeem gemoderniseerd in Verkuyl (2008).

De tweede aanpassing betreft het punt $k$. Dit kan beter worden gezien als de index die wordt toegekend aan een gebeuren. Zoals het getal 27 kan worden gebruikt als staande voor een bepaalde datum in een maand, dus staande voor een interval van 24 uur, zo kan de index $k$ worden gezien als staande voor een gebeuren, waarmee $k$ (als natuurlijk getal) dus staat voor het interval dat het representeert. In de derde oppositie is $k$ ingebed in zijn eigen heden $j$. Tabel 1 laat zien dat gebeurens een eigen heden $j$ hebben waarin ze zijn gepositioneerd als voltooid $(k<j)$ of waarin men niet weet of ze voltooid zijn $(k \leqslant j)$. Het heden van een gebeuren dient niet te worden verward met de looptijd ervan: als een vergadering valt op een middag, dan kan de hele middag dienst doen als heden voor die vergadering, terwijl de looptijd zelf tussen twee en drie uur valt.

Tenslotte de derde aanpassing: de index $j$ kan nu worden begrepen als verbinding tussen $k$ enerzijds en $i$ of $i^{\prime}$ anderzijds. De tweede oppositie heeft semantisch gezien tot taak om het hedendomein (of verledendomein) van spreker en hoorder te verbinden met het heden van $k$. Dat kan door de relatie tussen $j$ enerzijds en $i$ of $i^{\prime}$ anderzijds te zien als synchroon $\left(i \approx j\right.$ of $\left.i^{\prime} \approx j\right)$ of als posterieur $\left(i<j\right.$ of $\left.i^{\prime}<j\right)$.

In het resterende deel van $\S 2$ bespreken we kolom 1 van Tabel 2 om enkele consequenties van het loslaten van $n$ als heden na te gaan. In $\$ 3$ wordt beargumenteerd dat kolom 2 in het Nederlands niet binnen het werkwoordelijke systeem wordt uitgedrukt. De informatie die door het werkwoord zullen wordt bijgedragen, is puur modaal en de posterioriteitslezing die vaak te vinden is in zinnen met zullen kan worden verklaard in termen van pragmatische overwegingen, meer in het bijzonder: de werking van het Maxime van 
Kwantiteit van Grice. ${ }^{1}$ In $\S 4$ wordt de rol van de pragmatiek in de interpretatie van tempusinformatie behandeld.

\subsection{Alles wat zich laat aanzien op $n$}

Er zijn goede argumenten om de notie van heden wezenlijk te zien in termen van een domein dat voor spreker en hoorder als zodanig geldt en om aan het permanent vliedende nu-punt $n$ een eigen status te geven in dat domein. Zinnen als (3) laten zien hoe verbazingwekkend het eigenlijk is dat men in de tempusliteratuur steeds maar weer teruggrijpt op het nu-punt als heden.
a. Ik kook nu.
b. Ik kook vandaag.
c. Ik kook in april.

Los van de context drukken de drie zinnen in precies dezelfde mate en op precies dezelfde wijze onzekerheid uit. In (3a) kan de zin betekenen dat de spreker op dit moment bezig is te koken, maar de zin laat ook de mogelijkheid open dat het koken straks of vanavond kan plaatsvinden. Of zelfs over drie weken als het gaat om de herziening van een kookafspraak waar de spreker voor een ander invalt. Zin (3b) kan gebruikt worden om iemand die binnenkomt, te verklaren waarom de spreker achter het fornuis staat, maar de zin kan ook verklaren waarom hij/zij net boodschappen heeft gedaan voor het door hem/haar te bereiden avondeten. Iets soortgelijks geldt voor (3c): de zin kan voorafgaan aan de maand april, maar kan ook als verklaring dienen voor het feit dat de spreker nu in april staat te koken, terwijl iemand anders in mei het koken voor zijn/haar rekening neemt.

In alle drie de gevallen kan de zin betrekking hebben op het geactualiseerde deel van het heden dat we aanduiden als $i_{\mathrm{a}}$, maar ook op het nog niet geactualiseerde gedeelte ervan dat we aanduiden als $i_{\diamond}$. In (3a) - (3c) kan het heden zowel samenvallen met het interval dat door de adverbiale bepaling wordt genoemd als ook met een interval dat uitgebreider is dan het adverbiale interval. Zo kan (3c) deel zijn van een gesprek waarin het gaat over een heel jaar waarin allerlei taken worden vastgelegd. Dit laat zien er sprake is van een contextueel bepaald heden dat als zodanig functioneert voor spreker en hoorder. Zolang zij tegenwoordige tijdsvormen gebruiken, positioneren ze gebeurens in het voor hen als heden fungerende domein $i$, waarbij $i$ soms expliciet genoemd wordt en soms niet.

De verledentijdszinnen in (4) kunnen op dezelfde wijze geanalyseerd worden.
a. Ik kookte toen.
b. Ik kookte die dag.
c. Ik kookte in april.

1 Dat betekent dat op de morfosyntactische plek van de operatoren SYN en POST ruimte moet worden gemaakt voor modale informatie. De technische vraag hoe de opposities 1 en 3 zo met elkaar zijn te verbinden dat het temporele verband tussen PRES en PAST enerzijds en IMP en PERF anderzijds kan worden gelegd zonder te verhinderen dat modale operatoren de hun toekomende positie innemen, wordt beantwoord in Broekhuis $\delta$ Verkuyl (2014). 
De PAST-operator introduceert op analoge wijze een domein (het toen-heden $i^{\prime}$ ) inclusief een (virtueel) vliedend punt $n^{\prime}$ dat $i^{\prime}$ in tweeën splitst. Zo heeft zin (4a) de mogelijkheid om zich te richten op het geactualiseerde deel $i$ 'a ('ik was op dat moment aan het koken') of op het niet-geactualiseerde deel $i^{\prime}$ ('ik zou die avond (of die maand) gaan koken').

Dat een hedendomein $i$ zeer groot kan zijn, blijkt uit een zin als (5).

Sinds de oerknal breidt het heelal zich in alle richtingen uit en waarschijnlijk duurt dat voort tot het einde der tijden.

Natuurlijk kan men over het heelal en de oerknal in de verleden tijd praten: Sinds de oerknal breidde het heelal zich in alle richtingen uit ..., maar in zo'n geval is er toch duidelijk een ander perspectief van waaruit deze informatie moet worden bekeken. Dat een dergelijk perspectief buiten het heelal moet worden gevonden maakt de interpretatie van de verleden tijdsvorm in dit geval overigens erg lastig.

Een heel natuurlijk voorbeeld van de taakverdeling tussen $i$ en $j$ is te vinden in (6).

(6) a. Elsa werkt deze week aan de paragraaf over het tempussysteem.

b. Gisteren heeft ze de algemene opbouw vastgesteld.

c. Vandaag schrijft ze de inleiding.

d. Daarna gaat ze de acht tempusvormen beschrijven.

e. Ze zal het zaterdag wel voltooid hebben en als dat niet lukt doet ze dat zeker volgende week.

Zin (6a) identificeert het domein $i$ of een onderdeel ervan- $i$ zou ook betrekking kunnen hebben op de eerste helft van het lopend jaar, maar ook op volgende week zoals mogelijk aangegeven in (6e) - en daarin worden de gebeurens $k$ ingebed. Het heden $j$ van de $k$ in (6b) verschilt essentieel van de $j$ in (6c): in (6b) staat $j$ voor 'gisteren of een deel ervan', in (6c) voor 'vandaag of een deel ervan'. Ondanks dit verschil worden beide $j$ 's beschouwd als synchroon met $i$ omdat $i$ in dit geval het overkoepelende domein is voor de beide gebeurens $k$. Merk op dat de adverbiale bepalingen in (6b) en (6c) onderdeel uitmaken van het heden dat is vastgesteld via (6a), of eerder in de discussie waarvan (6) deel uitmaakt. Hier moet benadrukt worden dat gaat in (6d) en zal in (6e) tegenwoordige tijdsvormen zijn met exact dezelfde temporele betekenis als de andere finiete vormen: beide veronderstellen op dezelfde wijze als werkt, heeft, schrijft en lukt een hedendomein. Met andere woorden, afgezien van de lexicale verschillen tussen de infinitiefvormen is er geen verschil in analyse tussen PRES+schrijven, PRES+hebben enerzijds en PRES+gaan en PRES+zullen anderzijds: in alle gevallen wordt een strikte scheiding gemaakt tussen de bijdrage van de finiete presensvorm en die van de infinitiefvormen. ${ }^{2}$

2 Merk op dat gaan net als de andere werkwoorden op het moment van spreken kan worden gebruikt voor iets dat zich dan afspeelt. De dialoog A: Wat keek Emma sip. B: Ze gaat nu ontslag nemen. kan plaatsvinden als de twee gesprekspartners Emma de kamer binnen zagen gaan waarin ze nu bij haar baas zit om ontslag te nemen. De aanloop tot het ontslag nemen wordt door gaan uitgedrukt gelijktijdig met het spreken. Merk ook op dat er een modaal element meespeelt: Emma kan ook terugkomen uit de kamer en meedelen dat ze toch geen ontslag heeft genomen. Dat ligt niet aan gaan, maar aan PRES. 
Het is wellicht goed te wijzen op een punt waarop een externe beoordelaar ons attendeerde in verband met het verschil tussen zinnen als (7c) en (8c).
a. Gisteren heb ik het boek gelezen.
b. Ik heb het boek gisteren gelezen.
c. Ik heb het boek gelezen en wel gisteren.
a. Morgen heb ik het boek gelezen. (Dat beloof ik je.)
b. Ik heb het boek morgen gelezen.
c. ??Ik heb het boek gelezen en wel morgen.

De defaultinterpretatie van PRES in $I k$ heb het boek gelezen is door de $k<j$-informatie veel gemakkelijker toe te passen in de zinnen in (7): de adverbiale bepaling sluit heel goed aan op die interpretatie. In (8a) is de lokalisatie in $i$ door PRES vanaf het begin aanwezig, in (8b) komt morgen iets later maar nog vóór het hoofdwerkwoord en dus binnen de predicatie zelf, waardoor ook voorwaarts wordt geïnterpreteerd. In (8c) is sprake van de bekende 'garden path'-probleem: het tweede lid van de conjunctie is in strijd met de reeds voltooide defaultinterpretatie van het eerste en het is dan ook lastig om die alsnog in te ruilen voor de $i_{\diamond}$-interpretatie.

Terugkerend naar het verschil tussen het hedendomein en het vliedende punt $n$, kunnen we de voordelen van een strikte scheiding tussen beide noties nu beter zien: het vliedende nu wordt ontdaan van zijn taak om gebeurens te herbergen (het blijft een ondeelbaar punt), het heden kan daardoor worden gezien als een veelal contextueel bepaald domein waarin een spreker de tegenwoordige tijd gebruikt en waarin een groot aantal gebeurens kan worden ondergebracht als behorend tot het heden van spreker en hoorder. Het vliedende punt $n$ heeft als enige functie om in een temporeel domein een scheiding aan te brengen tussen een deel ervan dat reeds geactualiseerd is en een deel dat nog niet geactualiseerd is. Midden op de dag die we vandaag noemen en ons al pratend op het vliedende punt $n$ bevindend, is de ochtend het tot nu toe geactualiseerde deel van het heden dat we als vandaag ervaren terwijl de middag en de avond het deel vormen dat nog geactualiseerd moet worden (als alles meezit). De toevoeging tussen haakjes kan men desgewenst vervangen door deo volente of soortgelijke relativeringen die aangeven dat je nooit zeker bent van wat gaat komen.

Het verschil tussen enerzijds $i$ als hedendomein en $i^{\prime}$ als het verledendomein (= toen heden) enerzijds en het vliedende $n$-punt is te zien in Figuur 1, waar $n$ is weergegeven als een eendimensionale lijn die een tweedimensionaal gegeven domein scheidt in twee delen: het hedendomein $i$ wordt gescheiden in $i_{\text {a }}$ en $i$. 

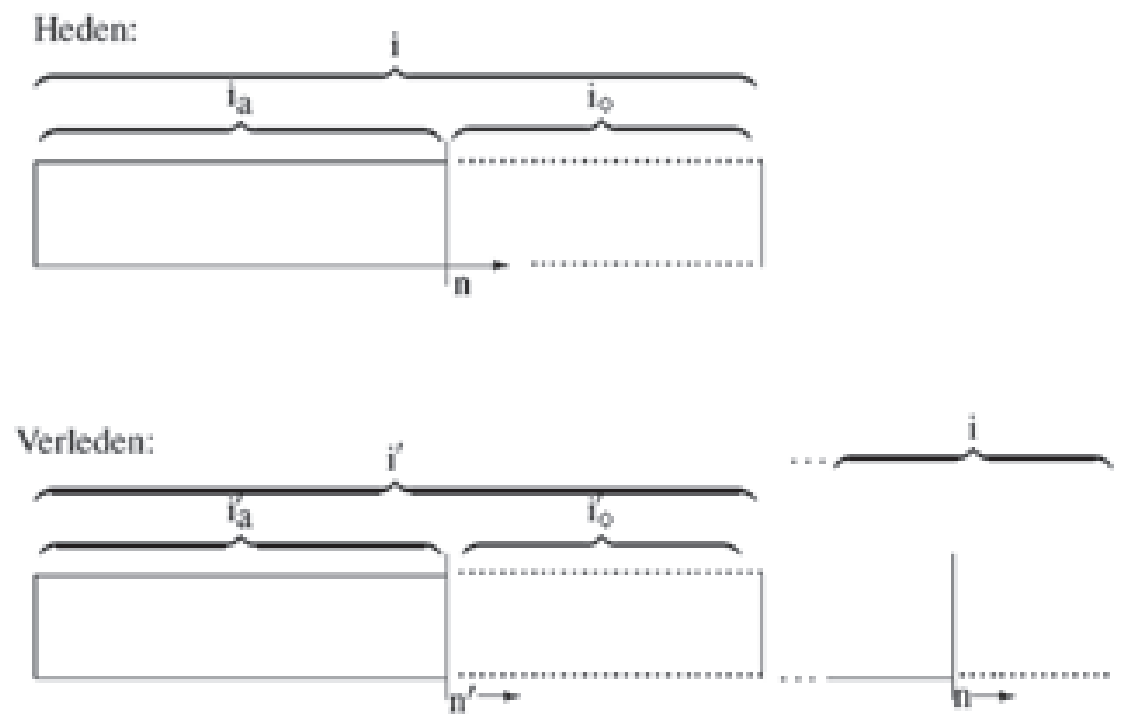

Figuur 1: Het hedendomein i en het verledendomein i'

De onderste helft van Figuur l laat zien dat bij gebruik van een verleden tijdsvorm, het hedendomein van spreker en hoorder altijd aanwezig blijft in de gesprekssituatie, als overkoepelend domein. Er is in feite geen gesprek mogelijk zonder dat $i$ aanwezig is: wat in het verleden gebeurd is, wordt altijd een plaats gegeven ten opzichte van de $i$ van spreker en hoorder. ${ }^{3}$ Door $n$ als een (verticale) lijn te representeren wordt duidelijker dat $n$ niet staat voor een tot punt samengetrokken representant van het spreken, maar dat $n$ altijd "meegaat" met elk uitgesproken woord in een spreekhandeling, maar ook met elke gesprekspauze in een spreeksituatie. Vandaar dat $i$ on uitdrukt dat het glijdende punt $n$ deel uitmaakt van het heden $i$. Figuur 1 laat ook zien dat in het verleden domein de pendant van $n$ aanwezig is als een virtueel spreekmoment $n^{\prime l}$ : ook een verleden domein wordt gesplitst in een geactualiseerd deel $i^{\prime}$ a en een niet-geactualiseerd deel $i_{\diamond}^{\prime}$.

Op dit punt moet natuurlijk wel vastgesteld worden dat Figuur 1 alleen het domein van spreker en hoorder representeert en geen informatie geeft over $j$ en $k$. We lieten bij de behandeling van (3a) - (3b) al zien dat $j$ en $k$ zowel in $i_{\text {a }}$ als in $i_{\diamond}$ kunnen worden geplaatst tenzij er voldoende informatie aanwezig is om een van de twee opties uit te sluiten, maar dit geldt ook voor andere drie PRES-vormen. In de eerste vier zinnen van tabel 1 sluit alleen Ik zal koken uit dat de zin betrekking heeft op $i_{\text {a }}$. Dit komt door het gebruik van $i k$, want in Jan zal koken kan Jan op het moment van spreken aan het koken zijn (dus in $i_{\text {a }}$ zelf) maar de zin kan ook van toepassing zijn op de locatie van $k$ in $i_{\diamond}$. In $I k$ zal hebben gekookt kan $k$ wel in $i$ a worden geplaatst omdat de zin uitdrukt dat de spreker niet meer zeker weet of hij op een contextueel bekend tijdstip in $i_{\text {a }}$ heeft gekookt.

3 In die zin is het onjuist om, zoals in Kirsner (1969: 105f.) en ook Janssen (1988), de primaire oppositie in (1a) te zien in termen van Verleden vs. Niet-Verleden, met Verleden als gemarkeerd lid ervan tenzij bedoeld wordt dat $i$ in feite de defaultwaarde is en $i^{\prime}$ gemarkeerd is omdat het altijd ten opzichte van $i$ moet worden vastgesteld en nooit uit zichzelf optreedt. 
Tabel 3 geeft een beeld van de verandering van Te Winkels binaire tempussysteem voorgesteld in Broekhuis \& Verkuyl (2014). De tweede oppositie wordt door het verdwijnen van zullen als temporeel werkwoord ongedaan gemaakt; we geven dit aan met behulp van een stippellijn.

\begin{tabular}{|l|l|l|l|}
\hline & $\begin{array}{l}\mathrm{l} \text { verleden/heden } \\
\text { 1. Ik kook }\end{array}$ & $\begin{array}{l}2 \\
\text { (niet-)later }\end{array}$ & $\begin{array}{l}3 \\
\text { (on-) voltooid }\end{array}$ \\
\hline 2. Ik heb gekookt & $\mathrm{i} \circ \mathrm{n}$ & $\mathrm{i} \approx \mathrm{j}$ & $\mathrm{k} \leqslant \mathrm{j}$ \\
\hline 3. Ik zal koken & $\mathrm{i} \circ \mathrm{n}$ & $\mathrm{i} \approx \mathrm{j}$ & $\mathrm{k}<\mathrm{j}$ \\
\hline 4. Ik zal hebben gekookt & $\mathrm{i} \circ \mathrm{n}$ & $\mathrm{i} a<\mathrm{j}$ & $\mathrm{k} \leqslant \mathrm{j}$ \\
\hline 5. Ik kookte & $\mathrm{i}^{\prime} \circ \mathrm{n}\left(\right.$ met $\left.\mathrm{n}^{\prime}<\mathrm{n}\right)$ & $\mathrm{i}^{\prime} \approx \mathrm{j}$ & $\mathrm{k} \leqslant \mathrm{j}$ \\
\hline 6. Ik had gekookt & $\mathrm{i}^{\prime} \circ \mathrm{n}\left(\right.$ met $\left.\mathrm{n}^{\prime}<\mathrm{n}\right)$ & $\mathrm{i}^{\prime} \approx \mathrm{j}$ & $\mathrm{k}<\mathrm{j}$ \\
\hline 7. Ik zou koken & $\mathrm{i}^{\prime} \circ \mathrm{n}\left(\right.$ met $\left.\mathrm{n}^{\prime}<\mathrm{n}\right)$ & $\mathrm{i}^{\prime} \mathrm{a}<\mathrm{j}$ & $\mathrm{k} \leqslant \mathrm{j}$ \\
\hline 8. Ik zou hebben gekookt & $\mathrm{i}^{\prime} \circ \mathrm{n}\left(\right.$ met $\left.\mathrm{n}^{\prime}<\mathrm{n}\right)$ & $\mathrm{i}^{\prime} \mathrm{a}<\mathrm{j}$ & $\mathrm{k}<\mathrm{j}$ \\
\hline
\end{tabular}

Tabel 3: Te Winkels systeem in Broekhuis $\theta$ Verkuyl (2014).

De posterieure informatie is op twee manieren aanwezig in de tempusinformatie bijgedragen door de operatoren PRES en PAST. In 1, 2, 5 en 6 kan $k$ zowel in $i_{\text {a }}$ resp. $i^{\prime}$ a als in $i_{\diamond}$ resp. $i_{\diamond}^{\prime}$ zitten. Door de aanwezigheid van het modale zullen wordt $k$ in $i_{\diamond}$ resp. $i_{\diamond}^{\prime}$ geplaatst, maar dat is niet een specifieke eigenschap van zullen, want ook moeten en kunnen staan garant voor $i_{\mathrm{a}}<j$ en $i^{\prime}$ a $<j$. Tabel 3 laat duidelijk zien dat hedendomein en verledendomein op identieke wijze zijn opgebouwd. Beide zijn ze gedefinieerd in termen van een punt van spreken dat het domein in kwestie dynamisch splitst.

\subsection{De positionering van $k$ "ergens in $i "$}

Verkuyl (2008), en ook Broekhuis \& Verkuyl (2014), neemt het standpunt in dat de onzekerheid over de lokalisatie van $k$ in $i$ niet opgevat moet worden in termen van ambiguïteit van de operator PRES. Immers, PRES is de tempusvorm die het hedendomein $i$ introduceert of bevestigt en $i$ bestrijkt de som van $i_{\mathrm{a}}$ en $i_{\diamond}$. Derhalve ligt het meer voor de hand om PRES vaag, in de zin van onderinformerend, te noemen en de nadere precisering van de positie van $k$ in een subdomein van $i$ over te laten aan andere elementen in de zin die de al of niet gewenste informatie leveren. Enkele voorbeelden laten zien wat hier bedoeld wordt. Bij gebruik van $i k$ in $i k$ zal koken wordt op grond van de aanname dat de spreker goed

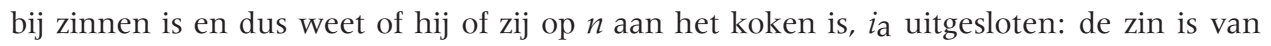
toepassing op $i_{\diamond}$. Toch is het niet altijd zo dat het gebruik van $i k$ de $k$ in $i$ positioneert. 
In $I k$ zal koorts hebben, door contextuele informatie begrepen als Ik zal (vermoedelijk) koorts hebben, ligt het meer voor de hand dat $k$ in $i$ a ligt. De positionering van $k$ hangt van de informatie tussen de haakjes af. De exacte plaatsing van $k$ in $i$ of $i^{\prime}$ is niet semantisch maar pragmatisch van aard: zonder nadere informatie kan men in zinnen als (9) niet uitmaken waar $k$ in $i$ moet worden geplaatst.
a. Marie doet haar best, daar ben ik van overtuigd.
b. Else zal hard werken aan haar hoofdstuk.
c. Veel mensen kunnen er niet zijn.
d. Ik geef deze keer een bijdrage van 50 euro aan het UAF.

Het is niet zinnig om de zinnen in (9) ambigu te noemen. Zoals ze er staan, onderinformeren ze de hoorder, zodat aanvullende informatie nodig is. Die informatie is niet noodzakelijkerwijs talig, maar komt vaak uit de context zelf. Als wij in (9c) afgaan op het geroezemoes van personen in een ruimte waar we naar binnen moeten, zal (9c) direct begrepen worden als een $i \mathrm{a}$-interpretatie. En deze $i_{\mathrm{a}}$-interpretatie van $(9 \mathrm{~b})$ is volstrekt duidelijk als net gevraagd is wat Else aan het doen is. Semantisch valt hier weinig te beleven. ${ }^{4}$

We besteden nogal wat aandacht aan de vraag of de operator PRES systematisch ambigu is of onderinformeert, omdat uit het antwoord kan worden afgeleid dat de notie van posterioriteit essentieel verbonden is met PRES en niet met de infinitiefvorm zullen. Immers, ongeacht het verschil tussen de infinitiefvormen doen, zullen werken, kunnen zijn en geven is het voor elk van de zinnen in (9) mogelijk om te verwijzen naar wat nog moet worden geactualiseerd in de reële tijd. Dat is toe te schrijven aan PRES, een operator die de instructie heeft om $k$ te positioneren ergens in $i$. En dit "ergens in $i$ " is niet een voldoende basis voor het gebruik van de term (structurele) ambiguiteit. Het ligt meer aan de structuur van het domein $i$ dat niet bij voorbaat duidelijk is waar $k$ terechtkomt dan dat er sprake is van taalstructurele onzekerheid.

\section{Modaliteit als onderdeel van het tempussysteem}

De karakterisering van PRES in termen van "ergens in $i$ " heeft als empirische consequentie dat aan de infinitiefvorm van zullen elke vorm van temporaliteit kan worden ontzegd. Natuurlijk, in zinnen als (10) krijgt zullen een plaats in een complexe temporele structuur, maar in termen van lokalisatie van het gebeuren-toch het primaire kenmerk van een tempusvorm-heeft het geen eigen bijdrage, net zo min als moeten en kunnen in (11).

4 Dat is ook het geval in de moderne interactie tussen personen via e-mail. In Ik lever mijn werkstuk in als pdf kan $k$ zowel in $i_{\text {a }}$ als in $i_{\diamond}$ gepositioneerd zijn. Dit geldt zolang de ontvanger van de mail nog niet kan zien of er een aanhangsel bijgevoegd is. Merk op dat we hier te maken hebben met een complexere beleving van het heden van spreker (in dit geval zender) en hoorder (in dit geval ontvanger) dan in een gesprek. Voor zender en ontvanger geldt dat ze het hedendomein behandelen alsof ze met elkaar in gesprek zijn. Dit laat des te meer zien dat de Heden-notie nooit kan samenvallen met het punt $n$, in dit geval het punt van schrijven $n$. Als er een week zit tussen zending en ontvangst telt het gebruik van de tegenwoordige tijd voor de ontvanger als liggend in het heden van de spreker. De $n$ van de zender is als het ware een week opgeschoven. 
(10) a. Zij had die avond zullen komen.

b. Ik weet zeker dat we zullen slagen.

(11) a. Zij had die avond moeten komen.

b. Ik weet zeker dat we kunnen slagen.

Het verschil tussen (10a) en (1 la) ligt in de aard van de garantie die gegeven was met betrekking tot haar komst. En uit (10b) spreekt simpelweg meer vertrouwen in de goede afloop dan uit (1 l b). Algemener, onze stelling is dat er in het Nederlands geen enkel voorbeeld te vinden is van een zin waarin zullen uitsluitend temporeel zou zijn en moeten en kunnen in diezelfde zin alleen maar modaal. ${ }^{5}$

We bekijken nu nader de eerste vier zinnen in (2) die we hier voor het gemak weer opvoeren als (12) en nemen aan dat ze worden uitgesproken door Els.

(12) a. Marie moet een afspraak met hem maken.

b. Marie kan een afspraak met hem maken.

c. Marie zal een afspraak met hem maken.

d. Marie maakt een afspraak met hem.

Het leidende idee is dat alle onderstreepte tempusvormen op exact dezelfde wijze participeren in de temporele informatie die door de zinnen in (12) worden gegeven, namelijk dat het hier gaat om een presensvorm waarin de onderinformatie bij Els over de exacte locatie van $k$ in $i$ in alle gevallen op dezelfde wijze aanwezig is.

Dit punt is het eerste verschil met Kirsner (1969:120) met wie wij onze analyse zullen vergelijken omdat ook hij van mening is dat moeten, kunnen en zullen een trio vormen dat onder één noemer valt: het eerste verschil is dat Kirsner (12d) niet in hetzelfde patroon zet als de eerste drie zinnen in (12). Daarmee miskent hij het feit dat deze zin op dezelfde wijze modaliteit uitdrukken als de andere drie zinnen behoudens de onderlinge lexicale verschillen.

Het tweede verschil is dat Kirsner nog geen gebruik kon maken van de pas later tot bloei gekomen mogelijke wereldensemantiek en daardoor tot minder nauwkeurige interpretatieverschillen tussen (12a) - (12c) kon komen dan thans mogelijk is. Zo neemt hij aan dat zullen, moeten en kunnen alle drie een hypothetische veronderstelling uitdrukken over wat er gaat gebeuren, maar "moeten and kunnen differ from zullen in that they not only claim that an event is hypothetical, that its occurrence is somehow questioned, but also assert relative probabilities for its realization. Moeten asserts that the event is more likely, kunnen that it is less likely." (1969:120)

De modaliteit in de zinnen in (12) wordt tegenwoordig door de mogelijke-wereldensemantiek niet zozeer gezien in termen van waarschijnlijkheid, maar in termen van kwantificatie over mogelijke werelden. Figuur 2 illustreert zonder gebruik te hoeven maken van formeel-technische apparatuur precies wat in de zinnen (12) wordt uitgedrukt. Op de splitsing tussen $i_{\mathrm{a}}$ and $i_{\diamond}$ ligt het bewegende punt $n$ ten opzichte waarvan zich

5 Dat men niet goed kan zeggen ??Zij heeft gisteren zullen wandelen is toe te schrijven aan het feit de voltooid tegenwoordige tijd niet echt geschikt is voor epistemische modale hulpwerkwoorden: ??Hij heeft gisteren moeten/ kunnen wandelen. 
mogelijke werelden voordoen, d.w.z. ruwweg situaties waarin de zinnen in (12) waar kunnen zijn of niet.

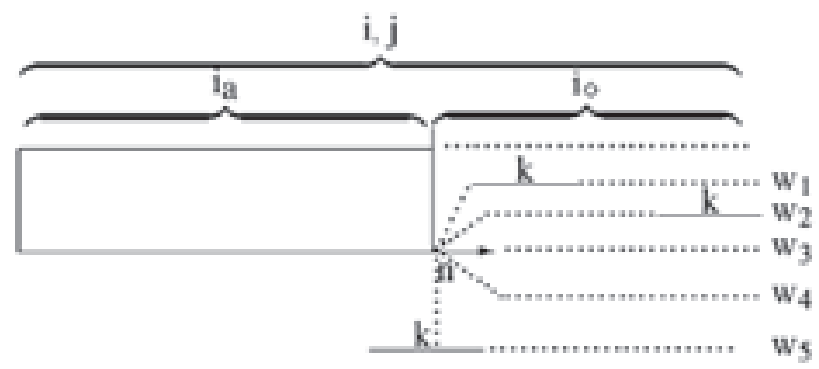

Figuur 2: Tegenwoordige tijd en mogelijke werelden

Het domein $i$ is het subdomein van $i$ waarin zekerheid over de waarheid van een uitspraak ontbreekt. Stel, er zijn met betrekking tot de zinnen vijf mogelijke werelden (deze beperking is uitsluitend bedoeld om de uitleg te vergemakkelijken). Dan claimt (12a) dat de aan de spreker beschikbare informatie het onvermijdelijk maakt dat de zin in alle vijf mogelijke werelden in $i_{\diamond}$ waar is. Met andere woorden, moeten levert een garantie af die direct wordt gefalsifieerd als er toch een wereld is waarin $k$ niet geactualiseerd wordt. ${ }^{6}$ In (12b) daarentegen sluit de spreker niet uit dat er een mogelijke wereld is waarin $k$ geactualiseerd wordt. Met waarschijnlijkheid heeft het verschil tussen moeten en kunnen weinig van doen: het verschil tussen (12a) en (12b) is een verschil tussen de universele kwantor 'voor alle werelden $w^{\prime}$ en de existentiële kwantor 'er is minstens een wereld $w^{\prime}$. Zoals bekend, laat de existentiële kwantor toe dat $k$ toevallig ook in alle werelden wordt geactualiseerd.

Het modale werkwoord zullen kan niet worden geïnterpreteerd worden als een logische kwantor. In termen van informatie die de spreker aan de hoorder verstrekt, kan de betekenis van zullen worden gekarakteriseerd als 'gezien de informatie die ik als spreker heb, is het in hoge mate aannemelijk dat ...'. In die zin geeft de spreker aan dat voor een voldoende grote meerderheid van mogelijke werelden met enige zekerheid gesteld kan worden dat de actualisatie van $k$ plaats vindt in $i_{\diamond}$. Vergeleken met de stelligheid van (12d) is de modaliteit van (12c) een bescheidener vorm van zekerheid.

Overigens zijn er twee vormen van in-hoge-mate-aannemelijkheid verbonden met zullen in de zin van: 'ik heb voldoende vertrouwen in mij beschikbare informatie om te kunnen zeggen dat'. Kwantitatief geldt de vertrouwensvolle verzekering van de spreker het aantal in beschouwing genomen werelden, kwalitatief gaat het om een blijkbaar aanwezige graad van vertrouwen die berust op een nadere, diepere inspectie van een aantal werelden (bijv. de spreker van (12c) heeft Marie zien lopen in het gebouw aan de overkant en neemt op grond van die waarneming en op grond van wat ze verder weet van Marie aan dat zij op weg is naar een afspraak). Belangrijk is te zien dat geen van de vier zinnen in (12) betrekking heeft op een reeds geactualiseerde $k$. Ook dit is geen semantische kwes-

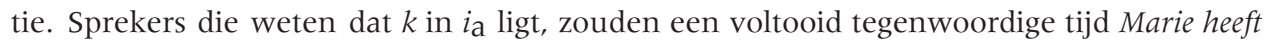


een afspraak met hem gehad hebben gebruikt, omdat juist die presensvorm de actualisering van $k$ in $i$ a aangeeft met $k<j$. We komen op dit punt terug in $\S 4$.

We bekijken nu nader de zinnen in (13), eveneens uitgesproken door Els.

(13) a. Marie moest deze week een afspraak met hem maken.

b. Marie kon deze week een afspraak met hem maken.

c. Marie zou deze week een afspraak met hem maken.

d. Marie maakte deze week een afspraak met hem.

e. Marie ging deze week een afspraak met hem maken.

Allereerst valt op dat de (13d) wat de modaliteit betreft niet meedoet met de andere vier zinnen. Dat is toe te schrijven aan de aanwezigheid van deze week, want in zinnen als Jan zou eerst gaan bellen, Christine zou vervolgens de situatie toelichten en Marie maakte dan een afspraak met hem is het wel degelijk mogelijk om het imperfectum modaal te gebruiken, zij het wat geforceerd. ${ }^{7}$ Figuur 3 laat zien dat door het gebruik van de Verleden tijd de splitsing in mogelijke werelden kan worden geplaatst in de verleden pendant van $n$, het virtuele moment $n^{\prime}$ dat in het verleden domein $i^{\prime}$ ligt.

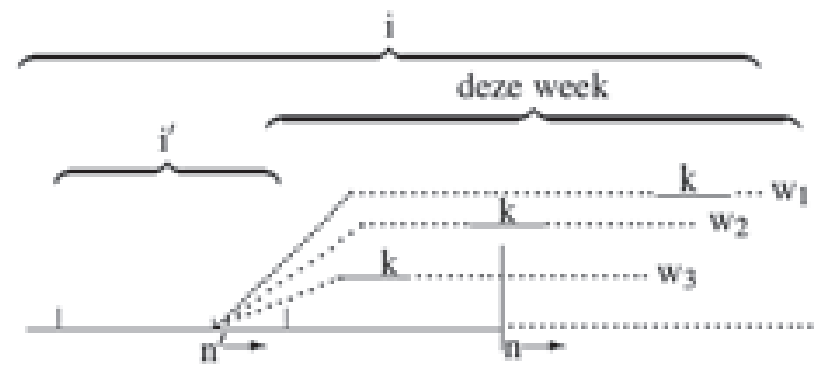

Figuur 3: Het verledendomein i' als deel van een groter hedendomein $\mathrm{i}$

De temporele interpretatie van (13a) - (13c) hangt volledig af van de kennis van Els over de actualisering van $k$. Als zij ondergeïnformeerd is en derhalve niet weet of $k$ al geactualiseerd is, dan kan $k$ in alle drie gevallen gelokaliseerd zijn vóór $n$, maar ook daarna, zoals zichtbaar is in de drie getekende werelden van Figuur 3. Is Els niet ondergeïnformeerd en weet zij dat $k$ al geactualiseerd is, dan misleidt zij de hoorder die immers mag uitgaan van het Maxime van kwantiteit. ${ }^{8}$ Zij had dan de zinnen moeten vervolgen met: . . en dat is inmiddels gebeurd. Of zij had direct kunnen kiezen voor Marie heeft deze week een afspraak met hem gemaakt of in mindere mate voor (13d). Als zij dat niet doet, dan mag de hoorder aannemen dat Els niet zeker weet of $k$ al geactualiseerd is. Ook op dit punt komen we terug $§ 4$.

7 Zie Broekhuis \& Verkuyl (2014) voor een nadere analyse van dit verschil tussen pres en past.

8 Het Maxime van kwantiteit van de taalfilosoof Paul Grice dicteert dat je als spreker niet te weinig en niet teveel informatie moet geven. In het hier beschreven geval is sprake van misleiding omdat Els door de keuze van haar bewoordingen ten onrechte de indruk wekt dat ze niet weet dat $k$ al geactualiseerd is; zie $\$ 4$ voor een verdere illustratie van dit maxime. 
Deze analyse geldt in gelijke mate voor moeten, kunnen en zullen. Er is dus niets specifieks temporeels aan zullen dat de karakterisering van dit werkwoord als hulpwerkwoord van tijd rechtvaardigt. Hetzelfde geldt overigens voor het werkwoord gaan in (13e): ook dat dient niet beschouwd te worden als een hulpwerkwoord van (toekomende) tijd. Een zin als Max gaat een boek schrijven over China zegt iets over de nu relevante voorbereidende fase van Max' feitelijke schrijven. Er is net zo weinig reden om gaat hier hulpwerkwoord van tijd te noemen als wil in Max wil een boek schrijven over China. De zin met gaat duidt op een iets verder gevorderd stadium.

\section{De rol van de pragmatiek}

In de vorige paragrafen hebben we beargumenteerd dat het gebruik van de operatoren PRES en PAST de index $k$ op een willekeurige plek in $i$ of $i^{\prime}$ lokaliseert: $k$ kan zowel in het geactualiseerde als het niet-geactualiseerde deel van het relevante temporele domein geplaatst worden. Verder hebben we betoogd dat zullen geen hulpwerkwoord van de toekomende tijd is, maar net als moeten en kunnen een modaal werkwoord: het doet een uitspraak over het voorkomen van $k$ in de toegankelijke mogelijke werelden. Verder hebben we gesuggereerd dat een eventuele inperking van het temporele domein waarin $k$ gelokaliseerd wordt een zaak van de pragmatiek is, meer in het bijzonder het zogenaamde Maxime van kwantiteit. De laatste stelling zullen we hieronder verder uitwerken.

Het Maxime van kwantiteit volgt uit het meer algemene coöperatieve principe beschreven in Grice $(1975 ;$ 1989) dat stelt dat sprekers (onbewust) hun bijdrage aan een discussie optimaliseren om een bepaald met de hoorder(s) gedeeld einddoel te bereiken. Sprekers houden zich daarom in het algemeen aan de vier maximes in (14) en hoorders zullen de uitingen van de spreker ook in het licht van deze maximes interpreteren.

(14) a. Maxime van kwantiteit: geef niet meer of minder informatie dan nodig is.

b. Maxime van kwaliteit: geef informatie die waar is of door voldoende feiten ondersteund wordt.

c. Maxime van relatie: geef informatie die relevant is.

d. Maxime van wijze: geef informatie die helder en ondubbelzinnig is.

Het coöperatieve principe dwingt de hoorder zinnen van een spreker over een gebeuren $k$ altijd te bezien in het licht van de (vermeende) kennistoestand van de spreker. Voor ons doel is vooral relevant of de spreker al dan niet volledig geïnformeerd is over actuele situatie rond $k$. Deze kennistoestand is van cruciaal belang voor het bepalen van de lokalisering van $k$. We vooronderstellen daarbij een context die de hoorder(s) in staat stelt een juiste inschatting te maken van de feitelijke kennistoestand van de spreker met betrekking tot $k$.

We beginnen met een bespreking van de tegenwoordige-tijdzinnen in (12). Neem aan dat de hoorder weet dat de Els niet volledig op de hoogte is van het doen of laten van Marie in de periode aangeduid door de adverbiale bepaling deze week. In dat geval treedt de defaultlezing op de voorgrond. Dat blijkt uit het feit dat Els de uiting in dat geval kan 
laten volgen door een zin als: Misschien heeft ze dat al gedaan, waarmee duidelijk wordt dat voor haar $k$ ook gesitueerd kan zijn in $i_{\text {a }}$.

Neem nu aan dat Els wel volledig geïnformeerd is. Zij komt op woensdag bij de hoorder en vertelt dat zij net met Marie gesproken heeft en spreekt daarna een van de zinnen in (12) uit. In zo'n geval zal de hoorder concluderen dat Marie de afspraak nog niet gemaakt heeft en dat $k$ dus in $i$ gesitueerd moeten worden. De (onbewuste) redenering van de hoorder die tot deze conclusie leidt, verloopt ongeveer als in (15):

(15) a. De spreker weet of gebeuren $k$ al dan niet heeft plaatsgevonden.

b. In elk van de zinnen in (12) gebruikt de spreker PRES+IMP.

c. De ongemarkeerde manier om uit te drukken dat $k$ heeft plaatsgevonden voor spreekmoment $n$ (dus in $i_{\mathrm{a}}$ ), is door gebruikmaking van PRES+PERF.

d. Uit het gebruik van PRES+IMP volgt daarom dat $k$ daarom niet gelokaliseerd in $i_{\text {a }}$.

e. Gebeuren $k$ moet derhalve gelokaliseerd worden in $i$.

Het Maxime van kwantiteit is ook werkzaam in het geval van de PAST-zinnen in (13), hoewel in dat geval het effect anders uitpakt. Els spreekt hier over $k$ vanuit het perspectief van een virtueel spreekmoment $n^{\prime}$ dat voorafgaat aan $n$. Neem aan dat de hoorder weet dat Els niet volledig op de hoogte is van het doen of laten van Marie in de periode volgend op $n^{\prime}$. In dat geval treedt de defaultlezing op de voorgrond. Dat blijkt uit het feit dat Els de uiting in dat geval kan laten volgen door een zin als: Maar ik weet niet of ze dat al gedaan heeft. Daarmee geeft Els aan dat $k$ gesitueerd kan zijn in $i$ a. ${ }^{9}$

Neem nu echter aan dat Els wel volledig geïnformeerd is. Els komt op woensdag bij de hoorder, vertelt dat zij net met Marie gesproken heeft, waarna zij een van de zinnen in (13) uit. In zo'n geval zal de hoorder concluderen dat Marie de afspraak nog niet gemaakt heeft en waarschijnlijk ook niet zal maken, d.w.z. dat hij met een counterfactual te maken heeft. De redenering die tot deze conclusie leidt moet niet alleen uitsluiten dat $k$ gelokaliseerd is in $i$, maar ook dat het gelokaliseerd is in $i$.

De redenering verloopt ruwweg als in (16), waarbij de hoorder aanneemt dat het verledendomein bevat is of kan zijn in het hedendomein.

(16) a. De spreker weet of gebeuren $k$ al dan niet heeft plaatsgevonden.

b. In elk van de zinnen in (13) gebruikt de spreker PAST+IMP.

c. De ongemarkeerde manier om uit te drukken dat $k$ heeft plaatsgevonden vóór spreekmoment $n$ (dus in $i_{\mathrm{a}}$ ), is door gebruikmaking van PRES+PERF.

d. Uit het gebruik van PAST+IMP volgt daarom dat $k$ niet gelokaliseerd in $i_{\text {a }}$.

e. De ongemarkeerde manier om uit te drukken dat $k$ plaatsvindt in $i_{\diamond}$ is door gebruikmaking van PRES+IMP.

f. Uit het gebruik van PAST+IMP volgt daarom dat $k$ niet gelokaliseerd is in $i$.

g. Gebeuren $k$ vindt noch in $i$ a noch in $i$ plaats, d.w.z. de zin is counterfactual.

9 We zien de term gebeuren als een niet-theoretische term en zijn sceptisch ten aanzien van de nogal uitbundige ontologie in de zogeheten event-semantiek. Vandaar dat we bijvoorbeeld in (15a) liever zouden spreken van een gebeuren aangeduid door de index $k$, waarbij $k$ een (natuurlijk) getal is dat (onze voorstelling van) een temporele entiteit representeert. Vandaar ook dat we omschrijvingen als 'situering van $k$ ' en 'plaatsvinden van $k^{\prime}$ zien als handige maar informele aanduidingen (vgl. Verkuyl 2008). 
De redeneerstappen in (16a) - (16d) zijn identiek aan die in (15a) - (15d) en laat dus uitsluitend plaatsing van $k$ in $i$ toe. De redeneerstappen in $(14 \mathrm{e}-\mathrm{g})$ laten echter zien dat dit ook niet mogelijk is: (14e) is in feite de conclusie in (13e). Omdat de combinatie PRES+IMP optimaal is om uit te drukken dat $k$ gelokaliseerd is in $i_{\diamond}$ sluit het Maxime van kwantiteit deze interpretatie uit voor de combinatie PAST+IMP. Dit zijn de stappen in (16e) - (16g). De conclusies (16d) en (16f) leiden gezamenlijk tot de conclusie (16g) dat $k$ niet gelokaliseerd is in het hedendomein en omdat het hedendomein het verledendomein kan omvatten zoals geschetst in Figuur 3, leidt dit tot de conclusie dat de zin counterfactual is: Els (de spreker-in-het-heden) geeft aan dat de verwachting van de virtuele spreker-in-hetverleden onjuist is gebleken. Merk op dat spreker en hoorder niet redeneren vanuit $n^{\prime}$ maar vanuit $n$. Vanuit $n^{\prime}$ zou men nooit tot een counterfactual kunnen besluiten! Daarom dat het cruciaal is dat domein $i$ domein $i^{\prime}$ kan bevatten en dat gebeurt in veel spreeksituaties (cf. Verkuyl 2008: hoofdstukken 485). De spreker presenteert het geheel vanuit $n^{\prime}$, maar evalueert vanuit $n$. Vandaar dat de spreker-van-het-heden kan aangeven en de hoorder kan begrijpen dat uiting van de (virtuele) spreker op $n^{\prime}$ onwaar is.

De discussie hierboven kunnen we samenvatten met behulp van tabel 4 .

\begin{tabular}{|l|l|l|}
\hline & \multicolumn{2}{|l|}{ kennistoestand spreker m.b.t. $k$} \\
\hline & onvolledig & volledig \\
\hline PRES & default: $i \approx j$ & posterieur: $i \mathrm{a}<j$ \\
\hline PAST & default: $i^{\prime} \approx j$ & counterfactual \\
\hline
\end{tabular}

Tabel 4: Informatieschema

Deze tabel laat zien dat de defaultinterpretatie van de operatoren PRES en PAST alleen aan het licht komt in het geval de spreker niet volledig op de hoogte is van de situatie met betrekking tot $k$ op het spreekmoment $n$. Is de spreker wel volledig geïnformeerd, dan kan het Maxime van kwantiteit speciale interpretaties bewerkstelligen: in het geval van PRES leidt dit tot een posterieure lezing en in het geval van PAST tot een counterfactual lezing. Het speciale effect kan overigens ook nog andere vormen aannemen, maar voor meer informatie zij vanwege ruimtebeperkingen verwezen naar Broekhuis \& Corver (2014).

\section{Conclusie}

De bedoeling van dit artikel was om te laten zien dat de principieel binaire opbouw van een tempussysteem afdwingt dat zullen als hulpwerkwoord van tijd geschrapt wordt. Dat onderscheidt de hier voorgestelde analyse essentieel van andere voorstellen om zullen uitsluitend als modaal te zien. Met name die (Reichenbachiaanse) systemen die een ternaire indeling van Verleden, Heden, Toekomst hanteren, schieten tekort in het aantonen van de noodzaak om zullen als temporeel hulpwerkwoord te schrappen. Het uitdrukken van 
posterioriteit gebeurt principieel door de presensvorm en de daarmee verbonden notie van een hedendomein dat gesplitst wordt in een geactualiseerd en een niet-geactualiseerd gedeelte. Essentieel is de onderinformatie die door een presensvorm sui generis wordt uitgedrukt. Contextuele informatie is nodig om $k$ in $i_{\text {a }}$ of in $i_{\diamond}$ exact te lokaliseren. Het Maxime van kwantiteit reguleert daarbij de interactie tussen spreker en hoorder: de hoorder interpreteert op basis van de veronderstelling dat de spreker in de keuze van zijn bewoordingen aangeeft wat hij weet en wat hij niet weet. 


\section{De modaliteit van temporaliteit}

\section{Abstract}

This contribution discusses three problems with the analysis of Dutch zullen ('will'/'shall') proposed by Verkuyl \& Broekhuis. First, they do not distinguish systematically between instances in which the finite form is constituted by the main verb and instances in which the finite form is an auxiliary such as zullen; the semantics they assume for PRES is too vague to capture the interpretation of tensed forms, especially that of epistemic modals. Second, both diachronic and synchronic evidence suggests that there cannot be an absolute distinction between the temporal and the modal reading of zullen. Third, tense itself may also be used to convey modality. This is particularly clear for the past tense of zullen and it cannot be captured by a temporal definition of PAST.

Meer nog dan bij het gemiddelde woord kan de bet. van zullen niet gë̈soleerd worden van die van den zin als geheel.

WNT

\section{Inleiding}

Verkuyl en Broekhuis (verder: V\&B) stellen in hun bijdrage een wijziging voor in de beschrijving die Verkuyl eerder, ook in dit tijdschrift (Verkuyl 2012), gaf van het tempussysteem van het Nederlands. Bij die beschrijving baseerde Verkuyl zich op het voorstel van Te Winkel (1866), van wie hij in eerste instantie het idee overnam dat, naast de opposities heden/verleden en voltooid/onvoltooid, ook het werkwoord zullen een plaats heeft in het tempussysteem. Die vorm zou volgens Te Winkel - en Verkuyl (2012) - geen toekomende tijd uitdrukken op hetzelfde niveau als heden en verleden, maar wel posterioriteit ('later dan'). In combinatie met de tegenwoordige tijd, zoals in (la), leidt dat tot een toekomstlezing ('later dan het spreekmoment'); in de verleden tijd, zoals in (lb), gaat het om posterioriteit ten opzichte van een moment in het verleden dat door de context gegeven moet zijn.

* Universiteit Leiden. Email: r.j.u.boogaart@hum.leidenuniv.nl 
a. Marie zal een afspraak met hem maken.

b. Marie zou een afspraak met hem maken.

V\&B stellen nu dat, bij nader inzien, het werkwoord zullen helemaal geen posterioriteit uitdrukt. De semantische bijdrage van dat werkwoord aan de interpretatie van de zinnen in (1) is niet temporeel, maar modaal. In termen van mogelijke werelden komt de betekenis van zullen er op neer dat 'voor een voldoende grote meerderheid van mogelijke werelden' gesteld kan worden dat de propositie waar is (of waar wordt). Iets informeler parafraseren zij die betekenis als volgt: 'gezien de informatie die ik als spreker heb, is het in hoge mate aannemelijk dat...'.

In (la) ligt het weliswaar voor de hand dat de modale evaluatie door de spreker betrekking heeft op een gebeurtenis in de toekomst, maar volgens V\&B is dat een implicatuur. Posterioriteit wordt in het Nederlands uitgedrukt door de onvoltooide tijden: net zo goed als (la) kan (2) gebruikt worden in een mededeling over een toekomstige gebeurtenis.

Marie maakt een afspraak met hem.

Een eventueel betekenisverschil tussen (la) en (2) heeft met de temporele locatie van het maken van de afspraak dus niets te maken. Volgens V\&B drukt (la) alleen een 'bescheidener vorm van zekerheid' uit dan (2).

Bovendien hoeven zinnen met zullen helemaal niet over de toekomst te gaan. Voor (la) is dat misschien lastig voor te stellen, maar volgens V\&B kan de zin ook gebruikt worden om een uitspraak te doen over het heden. In (3a) is die lezing expliciet gemaakt met de 'progressieve' aan het-constructie en het modale partikel wel.
a. Marie zal wel een afspraak met hem aan het maken zijn.
b. Marie zal wel ziek zijn - anders was ze aanwezig geweest.
c. Marie zal wel een afspraak met hem gemaakt hebben.

Ook als het complement van zullen een toestand is, zoals '(ziek) zijn' in (3b) of '(gemaakt) hebben' in (3c), ligt zo'n puur modale lezing - zonder enig idee van toekomst - veel meer voor de hand dan wanneer het complement een gebeurtenis is, zoals 'een afspraak maken' in (la) (vgl. Foolen \& De Hoop 2009). ${ }^{1}$ Opnieuw verschillen zinnen mét en zonder zullen niet principieel op dit punt: als het puur om de temporele locatie van de gebeurtenis gaat, is er weer geen verschil tussen de zinnen in (3) en hun zullen-loze equivalenten in (4).
a. Marie is een afspraak met hem aan het maken.
b. Marie is ziek.
c. Marie heeft een afspraak met hem gemaakt.

1 Het is niet duidelijk of V\&B deze opvatting van het voltooide complement in (3c) zouden delen, aangezien zij niet uitgaan van een analyse waarin het hulpwerkwoord hebben een eigen situatie aanduidt (zie paragraaf 2), maar het maakt een mooie generalisatie mogelijk over het verband tussen imperfectief aspect en epistemische modaliteit (Boogaart \& Trnavac 2011). 
Zulke voorbeelden ondersteunen dan ook de claim van V\&B dat de temporele interpretatie van zinnen met zullen niet door het werkwoord zullen zelf wordt bepaald. De tegenwoordige tijd in (1a) en in (3) wordt volgens hen niet anders geïnterpreteerd die in (2) en in (4). De onvoltooide tijden van het Nederlands zijn compatibel met posterioriteitslezingen, zoals blijkt uit (2), en dat geldt dus óók voor de tegenwoordige tijd in (1a). Het werkwoord zullen gedraagt zich in dit opzicht bovendien net zo als andere modale werkwoorden: als zullen in ( 1 ) en (3a)/(3b) vervangen wordt door een vorm van moeten of kunnen, verandert er niks aan de temporele interpretatie van deze zinnen (Janssen 1983: 67-68), en toch is niemand ooit op de gedachte gekomen om moeten en kunnen 'hulpwerkwoord van tijd' te noemen. Volgens V\&B hoeven we dat dus ook voor zullen niet te doen.

Het idee dat zullen geen hulpwerkwoord van tijd is, maar van modaliteit is niet nieuw. In de taalkundige beschrijving van het Nederlands is het zo algemeen aanvaard dat het een aantal inleidingen in de traditionele zinsontleding heeft gehaald (Luif 1994: 27,31; Van Santen z.j.). De betekenis die V\&B aan zullen toekennen, ligt bovendien dicht bij die in voorstellen van Kirsner (1969) en met name Janssen (1983, 1989a), die de betekenis omschrijft als 'er is genoeg reden om te zeggen dat...' (vgl. de 'voldoende grote meerderheid van mogelijke werelden' bij V\&B). Het voorstel van V\&B verschilt echter, los van de formalisering, op een cruciaal punt van deze eerdere voorstellen. Als ik het goed zie, zijn zij de eersten die voor de posterioriteitslezing van (1a) en (2) exact dezelfde bron aanwijzen, namelijk de temporeel gezien vage betekenis van de tegenwoordige tijd (PRES). In paragraaf 2 zal blijken dat precies dat punt in de analyse van V\&B nogal problematisch is.

In de rest van mijn reactie zal ik nog twee andere kwesties aan de auteurs voorleggen. De eerste betreft de vraag of een strikt onderscheid tussen de temporele en de modale lezing van zullen wel te verenigen valt met wat we weten over de diachronie van modale werkwoorden (paragraaf 3). Mijn laatste vraag is waarom V\&B modaliteit in het tempussysteem beperken tot posterioriteit en waarom ze geen oog hebben voor de algemenere modale betekenis van met name de verleden tijd - een kwestie die nogal urgent is in het licht van hun analyse van zou(den).

\section{De rol van finietheid en de gesprekssituatie}

Vooral vanwege zinnen als in (3) is het aantrekkelijk om aan te nemen dat het werkwoord zullen geen toekomende tijd uitdrukt. Deze zinnen gaan immers over het heden (of zelfs over het verleden, zoals in (3c)) en niet over de toekomst. De modale karakterisering van zullen in (3), waar het een hoge graad van waarschijnlijkheid uitdrukt, is vervolgens gemakkelijk te generaliseren naar het 'futurele' gebruik in (la).

a. Marie zal een afspraak met hem maken.

Sprekers kunnen nooit met absolute zekerheid over de toekomst spreken, dus enig idee van modaliteit is sowieso aanwezig in uitspraken over de toekomst. Wie een onderscheid wil maken tussen zullen als hulpwerkwoord van toekomende tijd en zullen als hulpwerkwoord van modaliteit, komt bij een eenvoudig zinnetje als (la) al meteen in de problemen: deze zin kan over de toekomst gaan, maar drukt ook dan uit dat de spreker het in hoge 
mate aannemelijk' vindt dat Marie de afspraak gaat maken. Een modale omschrijving van de betekenis van zullen is dus ruimer toepasbaar dan een temporele, en de toekomstlezing kan gezien worden als een specifiekere invulling van de modale betekenis. Dat is wat Kirsner (1969) op het oog heeft wanneer hij als overkoepelende betekenis van alle verschillende gebruikswijzen van zullen 'hypothetical' voorstelt.

Maar V\&B doen iets anders. Voor hen heeft de toekomstlezing van zinnen met zullen helemaal niks met de betekenis van zullen te maken. De betekenis die zij voorstellen ('in hoge mate aannemelijk') moet dan ook niet beschouwd worden als een poging om alle mogelijke interpretaties van dat werkwoord - modaal of temporeel - onder één noemer te vangen. Terwijl voor Kirsner (1969) het werkwoord zullen op grond van zijn betekenis op z'n minst geschikt is om door taalgebruikers ingezet te worden als toekomst-aanduider, bestáát in de opvatting van V\&B dat temporeel gebruik van zullen eigenlijk niet; in dat opzicht is hun voorstel eerder te vergelijken met dat van Janssen (1989a) dan met Kirsner (1969). Het lokaliseren van situaties in de tijd gebeurt volgens V\&B enkel en alleen door de oppositie tussen de tegenwoordige en verleden tijd (PRES/PAST), in combinatie met de oppositie tussen voltooide en onvoltooide vormen (PERF/IMP).

Aangezien de toekomstlezing van (la) en (2) volgens V\&B voor rekening komt van de tegenwoordige tijd, is het van belang eerst vast te stellen wat volgens hen de betekenis van PRES is. Die betekenis wordt vaak gedefinieerd als een relatie van gelijktijdigheid met het spreekmoment, maar zo'n karakterisering voldoet volgens V\&B niet. Dat blijkt natuurlijk al uit (2), waar het maken van de afspraak helemaal niet op het spreekmoment hoeft plaats te vinden.

Marie maakt een afspraak met hem.

V\&B concluderen daaruit niet dat het gebruik van tempus blijkbaar niet (alleen) met tijd te maken heeft (zie paragraaf 4), maar ze rekken de betekenis van PRES op: met het gebruik van een tegenwoordige tijd situeert de spreker een stand van zaken ergens in een heden-domein. Een relatie met het spreekmoment wordt door PRES niet tot uitdrukking gebracht: het spreekmoment splitst het heden-domein in een 'geactualiseerd' en een 'nietgeactualiseerd' deel, maar PRES als zodanig geeft geen informatie over de precieze temporele locatie van een stand van zaken binnen het heden-domein. De 'toekomstlezing' van ( la) en (2) wordt beschouwd als een interpretatie waarin het maken van de afspraak zich afspeelt in het niet-geactualiseerde deel van het heden. ${ }^{2}$ Die vorm van posterioriteit ten opzichte van het spreekmoment is compatibel met PRES en daarin speelt de aanwezigheid van het werkwoord zullen in (la) geen enkele rol. De vorm zal maken in (la) wordt door V\&B namelijk in z'n geheel als PRES beschouwd, en daarmee is de mogelijkheid van een posterioriteitslezing beschikbaar. V\&B stellen dat er in dit opzicht geen enkel verschil is tussen (la) en (2): in beide gevallen komt de mogelijkheid van een toekomstlezing op het conto van de temporele vaagheid van PRES.

Dat de toekomstlezing van (la) op dezelfde manier tot stand komt als die van (2) en te maken heeft met de betekenis van de tegenwoordige tijd, is een origineel aspect van

2 Naar het geactualiseerde deel van het heden kan de spreker verwijzen met een voltooid tegenwoordige tijd (Marie heeft een afspraak met hem gemaakt). 
het voorstel van V\&B, waarin het zich onderscheidt van dat van Janssen (1989a). ${ }^{3}$ Maar het is niet onproblematisch. Om dat duidelijk te maken, kunnen we hun analyse van de toekomst-interpretatie van (la) en (2) samenvatten als in Figuur 1.

\section{HEDEN}

\begin{tabular}{c|c|c}
\hline GEACTUALISEERD & Nu & NIET-GEACTUALISEERD \\
\hline & & zal een afspraak maken (la) \\
& & maakt een afspraak (2) \\
\hline
\end{tabular}

Figuur 1: de posterioriteitslezing van de tegenwoordige tijd volgens Verkuyl $\theta$ Broekhuis

Figuur 1 brengt twee problemen aan het licht voor de benadering van V\&B:

1. Er wordt geen duidelijk onderscheid gemaakt tussen de interpretatie van finiete en niet-finiete vormen: dat (een afspraak) maken alleen in (2) met een tegenwoordige tijd (maakt) wordt gepresenteerd, heeft geen consequenties voor de uniforme analyse van (la) en (2).

2. In de betekenis die V\&B voorstellen voor de tegenwoordige tijd, in termen van een heden-domein, ontbreekt een expliciete verwijzing naar de gesprekssituatie, maar die is voor het gebruik van finiete tempusvormen en modale werkwoorden onmisbaar.

\section{Finiete versus infiniete vormen}

Naar mijn gevoel zijn V\&B te ver doorgeschoten in hun wens om de tegenwoordige tijd van zullen in (la) op dezelfde manier te behandelen als de tegenwoordige tijd van zelfstandige werkwoorden als maken in (2). Voor (2) is het beter te verdedigen dan voor (la) dat de posterioriteitslezing volgt uit de betekenis van de tegenwoordige tijd (PRES), die in het Nederlands nu eenmaal ook voor de toekomst gebruikt kan worden. In (2) wordt de gebeurtenis als zodanig immers met een finiete tegenwoordigetijdsvorm van het werkwoord maken gepresenteerd. Wat de spreker hier doet is het maken van de afspraak ergens in een heden-domein situeren en op grond van contextuele, en vermoedelijk ook aspectuele (vgl. (2) met (4)), informatie kan die interpretatie specifieker worden ingevuld als '(nog) niet geactualiseerd'.

Maar in (la) is iets heel anders aan de hand. Hier gebruikt de spreker niet een finiete vorm van het zelfstandige werkwoord maken, maar van het hulpwerkwoord zullen. Voor V\&B lijkt dat niet zoveel uit te maken: ze behandelen zal een afspraak maken als één geheel dat, op grond van de PRES-informatie geleverd door zal, het maken van de afspraak 'ergens in het heden-domein' plaatst, exact zoals in (2). Het is wel de vorm zal die het kenmerk PRES levert, maar PRES wordt door V\&B opgevat als een operator die een afspraak maken in zijn bereik heeft. Hun analyse van samengestelde vormen als zullen+infinitief en overigens ook van hebben/zijn+voltooid deelwoord - kan wel compositioneel genoemd

3 Volgens V\&B volgt 'dwingend' uit hun model dat zullen niet temporeel kan zijn, maar het laat nog steeds de mogelijkheid open dat het Nederlands naast de onvoltooide tijd beschikt over een specifiekere, gemarkeerde vorm om expliciet over het niet-geactualiseerde heden te spreken. Iets dergelijks nemen V\&B immers wél aan voor de voltooid tegenwoordige tijd (zie noot 2). 
worden, maar niet op dezelfde manier als die van Janssen (1989a): in tegenstelling tot Janssen, beschouwen V\&B zal in (la) niet als de aanduiding van een situatie die in principe los van de situatie in het complement in de tijd gelokaliseerd kan worden; binnen het model van V\&B zou zo'n analyse eruit kunnen zien als in Figuur 2.

\begin{tabular}{c|c|c}
\hline \multicolumn{3}{c}{ HEDEN } \\
\hline GEACTUALISEERD & $\mathrm{Nu}$ & NIET-GEACTUALISEERD \\
\hline & $z a l$ & een afspraak maken \\
\hline
\end{tabular}

Figuur 2: een compositionele analyse van zullen + infinitief (naar Janssen 1989)

Toch is er juist bij (epistemische) modale werkwoorden alle reden toe om de interpretatie ervan op te vatten als in Figuur 2. De modale evaluatie van het maken van de afspraak als 'in hoge mate aannemelijk' gebeurt namelijk door de spreker op het spreekmoment, op grond van de informatie waarover hij in de gesprekssituatie beschikt. De vorm zal in (la) levert de informatie PRES maar het is niet zo dat de situatie die door zal wordt aangeduid, ook zelf in het niet-geactualiseerde heden gesitueerd kan worden, zoals V\&B suggereren. Als we aan (la) een temporele bepaling toevoegen die de tijd van het maken van de afspraak specificeert, zoals in (5), dan is een adequate parafrase daarvan die in (6a), niet die in $(6 b)$.

Marie zal morgen een afspraak met hem maken.

(6) a. Het is in hoge mate aannemelijk dat Marie morgen een afspraak met hem maakt.

b. Het is morgen in hoge mate aannemelijk dat Marie een afspraak met hem maakt.

Wat 'niet-geactualiseerd' is in (la), is niet de modale evaluatie, maar de situatie die met het infinitiefcomplement een afspraak maken wordt gepresenteerd. Die infinitief is echter niet - of althans niet zichtbaar voor taalgebruikers ${ }^{4}$ - een tegenwoordige tijd, en de temporele situering van het maken van de afspraak kan dus in (la) niet zonder meer aan PRES worden toegeschreven, of toch zeker niet op dezelfde manier als in (2). De tijd van een afspraak maken wordt in (la) bepaald door de relatie met de tijd van zal: dat kan een relatie van posterioriteit zijn, zoals in (la) voor de hand ligt, of van gelijktijdigheid, zoals bij de zinnen in (3). Volgens V\&B is dat verschil volledig pragmatisch, en inderdaad zijn alternatieve lezingen voor ( la) en (3) met enige moeite wel te bedenken, maar het is duidelijk dat de aspectuele informatie van het complement wel een indicatie over de ordening geeft (Foolen \& De Hoop 2009). De gelijktijdigheidslezing van (3b) en (3c) zou er in een compositionele analyse uit kunnen zien als in Figuur 3.

4 Men kan natuurlijk makkelijk aannemen dat infinitieven ook 'tense' hebben, of krijgen van de finiete vorm, maar mijn punt hier is dat bij V\&B een cruciaal verschil tussen de temporele interpretatie van finiete en infiniete vormen (of die nou wel of niet 'tense' hebben) verloren gaat. 


\section{HEDEN}

\begin{tabular}{c|c|c}
\hline GEACTUALISEERD & Nu & NIET-GEACTUALISEERD \\
\hline & zal & \\
ziek zijn & \\
een afspraakgemaakt & heben & \\
\hline
\end{tabular}

Figuur 3: een compositionele analyse van zullen + infinitief (statisch)

Ook Figuur 2 en Figuur 3 zijn in verschillende opzichten nog niet ideaal. V\&B hebben zeker gelijk dat 'gelijktijdigheid met het spreekmoment' niet zo'n gelukkige karakterisering is van de semantiek van de tegenwoordig tijd, dus inclusief die van zal in Figuur 2 en 3. Die notie is duidelijk te beperkt om alle gebruiksmogelijkheden van de tegenwoordige tijd te kunnen verklaren. Maar hun eigen voorstel om het spreekmoment uit de semantiek van PRES te weren en het te vervangen door een in principe oneindig heden-domein is dan weer te ruim. Tussen het 'vliedende nu-punt' van bijvoorbeeld Reichenbach (1947) en het heden-domein van V\&B bevindt zich namelijk nog de gesprekssituatie en finiete tempusvormen drukken wel degelijk een relatie met de gesprekssituatie uit.

\section{Heden-domein versus gesprekssituatie}

Door geen duidelijk onderscheid te maken tussen de interpretatie van finiete vormen, die zichtbaar PRES of PAST zijn, en infiniete vormen, worden V\&B gedwongen tot een wel heel ruime opvatting van de betekenis van PRES en PAST. V\&B beschouwen de combinatie van een hulpwerkwoord met een voltooid deelwoord of infinitief in hun geheel als PRES of PAST; de tempus-operatoren hebben het infiniete gedeelte in hun bereik. De situatie die met een niet-finiete vorm wordt gepresenteerd, moet dus door PRES of PAST in de tijd gelokaliseerd worden. Dat betekent dat niet alleen in hij doet het, maar ook in hij heeft het gedaan en in hij zal het doen, de temporele locatie van 'doen' zich bevindt in het heden-domein, dat dus oneindig groot kan zijn. Maar voor de interpretatie van finiete tempusvormen en epistemische modaliteit is een veel beperktere notie van belang, namelijk die van de gesprekssituatie.

Het is wat in de Cognitieve Grammatica van Langacker de Ground wordt genoemd: 'the speech event, its participants (speaker and hearer), their interaction, and the immediate circumstances (notably, the time and place of speaking)' (2008: 259). Zo'n soort notie, die meer omvat dan alleen het point of speech van Reichenbach maar (temporeel gezien) minder dan het heden-domein van V\&B, is nodig om het gebruik van tempus en (epistemische) modale werkwoorden adequaat te kunnen beschrijven. Tempus is deiktisch: door een situatie te presenteren met een tempusvorm (PRES/PAST) geeft de spreker aan dat die situatie verbonden is met de spreeksituatie; de keuze tussen PRES en PAST zegt iets over de specifieke relatie met de spreeksituatie. ${ }^{5}$ In (2) wordt het maken van de afspraak niet direct aan de spreeksituatie gekoppeld; de relatie met de Ground wordt gelegd via de finiete vorm zal. Het gevolg daarvan is dat het maken van de afspraak niet als deel van de

5 Die relatie hoeft zeker niet per se temporeel te zijn (zie paragraaf 4), al beschouwt Langacker (2011) zelf het temporele gebruik van de werkwoordstijden wel als prototypisch. 
werkelijkheid wordt gepresenteerd, maar dat de waarschijnlijkheid ervan door de spreker in de gesprekssituatie wordt geëvalueerd. Bij het gebruik van modale werkwoorden spelen de spreker en zijn mening en kennis op het moment van spreken - niet 'ergens' in het heden-domein - dus een cruciale rol; de epistemische lezing van modale werkwoorden wordt om die reden binnen de Cognitieve Grammatica als zeer 'subjectief' beschouwd (vgl. Boogaart $\&$ Fortuin, te versch.). Het is een aspect van de interpretatie van zal in (la) dat wel degelijk ook te maken heeft met de tegenwoordige tijd, maar dat in een opvatting als weergegeven in Figuur 1 niet tot uitdrukking kan komen.

Hoe nauw de band is tussen de gesprekssituatie en epistemische modaliteit, blijkt wel uit de claim, te vinden bij onder andere Abraham (2001) en Condoravdi (2002), dat modale werkwoorden alleen maar in de tegenwoordige tijd epistemisch geïnterpreteerd kunnen worden. Dat is duidelijk te sterk uitgedrukt (Boogaart 2007; Eide 2011), maar als een modaal werkwoord niet finiet is, wordt een epistemisch-modale lezing wel erg lastig, zoals blijkt in (7).

a. Marie moet/kan/zal een afspraak met hem gemaakt hebben.

b. Marie heeft een afspraak met hem moeten/kunnen maken. ${ }^{6}$

c. ?Marie heeft een afspraak met hem zullen maken.

In (7a), waar de persoonsvorm een modaal werkwoord is (moet/kan/zal), is een epistemische interpretatie bijna onvermijdelijk: de spreker zegt iets over de vraag hoe waarschijnlijk het volgens hem - op het spreekmoment - is dat Marie een afspraak heeft gemaakt. In (7b) en (7c) echter, is zo'n lezing eigenlijk niet beschikbaar. In (7b) worden moeten en kunnen bij voorkeur niet-epistemisch begrepen: Marie had de verplichting of was in staat om een afspraak te maken. Dat het werkwoord zullen in (7c) moeilijk te gebruiken is, levert een mooi argument voor de stelling van V\&B dat zullen altijd epistemisch-modaal is: voor moeten en kunnen zijn er alternatieve interpretaties beschikbaar, maar omdat dat voor zullen niet zo is, is het resultaat in (7c) twijfelachtig. ${ }^{7}$ Tegelijkertijd laten de zinnen in (7) zien dat er een onlosmakelijk verband bestaat tussen epistemische modaliteit, finietheid en de tegenwoordige tijd. V\&B proberen de betekenisbijdrage van PRES los te maken van de (lexicale) betekenis van de infinitief zullen. Dat is op zichzelf een goed idee, maar het is wel van belang te beseffen dat de epistemisch-modale lezing tot stand komt door de combinatie van PRES en de betekenis van zullen, en dat een notie als spreekmoment of Ground daarbij onmisbaar is. ${ }^{8}$

6 V\&B (noot 5) markeren dit type zinnen met twee vraagtekens, vermoedelijk omdat zij zich willen beperken tot de epistemisch-modale lezing, die hier inderdaad (bijna) niet beschikbaar is. Daar moet dan wel bij opgemerkt worden dat voor hun standaardvoorbeeld Marie moet/kan een afspraak met hem maken een epistemische lezing evenmin goed voorstelbaar is, vermoedelijk vanwege het niet-statische karakter van het complement.

7 De archaïsche variant met een verleden tijd, Marie had een afspraak zullen maken, is wel mogelijk, maar daarin drukt zullen alleen maar posterioriteit uit, wat op zichzelf een probleem is voor V\&B (zie paragraaf 3).

8 Volgens VEB is de notie spreekmoment problematisch, onder andere omdat het uitspreken van een zin (...) veel meer tijd in beslag [neemt] dan wat de strikte notie van punt toestaat'. Dat mag in de werkelijkheid zo zijn, het betekent natuurlijk niet dat taalgebruikers het moment van spreken niet als een punt zouden kunnen conceptualiseren. Voor een epistemische lezing van modale werkwoorden is gelijktijdigheid met een evaluatiepunt (meestal het spreekmoment) een noodzakelijke voorwaarde (Boogaart 2007). 
Door een niet volledig compositionele analyse van zullen+infinitief ${ }^{9}$ (zie Figuur 1 in vergelijking met Figuur 2 en Figuur 3) en door de semantiek van de tegenwoordige tijd te verruimen tot 'ergens in het heden-domein', verliezen V\&B naar mijn gevoel een wezenlijk aspect van de functie van finiete tempusvormen en van epistemisch-modale werkwoorden - én dus ook van het verschil tussen de zinnen in (la) en (2).

\section{De temporaliteit van zullen}

Dat zullen een hulpwerkwoord van modaliteit is, of óók als hulpwerkwoord van modaliteit gebruikt kan worden, valt moeilijk te ontkennen. Nu geldt niet alleen voor zullen maar voor alle modale werkwoorden dat ze heel verschillende gebruiksmogelijkheden hebben, die soms lastig van elkaar te onderscheiden zijn. Dat valt goed te begrijpen als je kijkt naar de ontwikkeling van de semantiek van modale werkwoorden door de tijd heen. Voor zullen is diachroon onderzoek schaars, maar dat geldt niet voor modale werkwoorden in het algemeen (zie bijv. Narrog 2012 voor een recent overzicht, vgl. voor het Nederlands Byloo $\varepsilon$ Nuyts 2012). Bovendien hebben we de beschikking over het voortreffelijke lemma voor zullen in het Woordenboek der Nederlandsche Taal. Als we dat als uitgangspunt nemen, kunnen we de ontwikkeling van de betekenis van zullen reconstrueren als in (8). ${ }^{10}$

$$
\text { (ver)schuldig(d) zijn > verplichting }>\text { toekomst }>\text { waarschijnlijkheid }
$$

Het gebruik van het werkwoord ontwikkelt zich dus waarschijnlijk van deontische modaliteit - een moeten-achtige betekenis als in het standaardvoorbeeld gij zult niet doden - naar epistemische modaliteit, van het type 'het is in hoge mate aannemelijk dat...' (V\&B). Volgens het WNT (en Duinhoven 1994) verloopt die ontwikkeling via een stadium waarin het werkwoord een toekomstbetekenis heeft ('verwachten', 'in het vooruitzicht hebben'), maar wel vaak 'met modale nuances'. Pas in het laatste stadium in (8) kan zullen waarschijnlijkheid uitdrukken zonder dat het de toekomst betreft; gevallen als in (3) hebben, in de woorden van het WNT, 'hun futuraal karakter geheel verloren'.

a. Marie zal wel een afspraak met hem aan het maken zijn.

b. Marie zal wel ziek zijn - anders was ze aanwezig geweest.

c. Marie zal wel een afspraak met hem gemaakt hebben.

9 Die niet-compositionele benadering wreekt zich ook in hun analyse van gaan+infinitief. V\&B willen gaan geen hulpwerkwoord van toekomende tijd noemen omdat de 'voorbereidingen' waar het werkwoord (volgens het WNT) naar verwijst, niet in de toekomst liggen. Die voorbereidingen, waarop de finiete vorm van gaan betrekking heeft, vinden inderdaad op het spreekmoment plaats; wat per definitie in de toekomst ligt, is de situatie die met de infinitief wordt gepresenteerd. In een compositionele analyse is het helemaal geen probleem dat een finiete tegenwoordige tijd onderdeel is van een constructie die in z'n geheel gebruikt wordt als een 'toekomende tijd'.

10 Als oorsprong wordt, net als voor het Engelse shall/should en het Duitse sollen, de Indoeuropese wortel (s)kelaangenomen, die ook nog terugkomt in een woord als schuld. Zie Harmes (2006) voor een eerste contrastieve analyse van zullen, sollen en shall. 
Hoe de ontwikkeling bij zullen precies is gegaan, zou verder moeten worden uitgezocht, maar er is - algemener - redelijk wat evidentie dat 'should-type modal markers (...) acquire a present-oriented epistemic meaning through a future-oriented epistemic meaning' (Narrog 2012:172, vgl. Fritz 1997 over het Duitse sollen). Een dergelijke ontwikkeling van een temporele betekenis (toekomst) naar een modale betekenis (epistemisch) wordt ook aangenomen voor andere werkwoorden (zie Sweetser 1990:62 over that will be John!); Boogaart (2009b) laat bovendien zien dat ook de modale interpretatie van het temporeel bijwoord straks in straks is hij nog ziek! en straks heeft hij een ongeluk gehad! verklaard kan worden uit de temporele betekenis, die een 'verificatiepunt' in de toekomst situeert ('straks blijkt nog dat...').

Wat betekent dit nu voor de analyse van V\&B? Zij beweren dat zullen alleen epistemische modaliteit uitdrukt en dat de toekomst-lezing niks te maken heeft met de semantiek van het werkwoord, maar 'essentieel' verbonden is met de tegenwoordige tijd. Die analyse komt er feitelijk op neer dat de betekenis van zullen intussen zozeer veranderd is dat het idee van toekomst volledig verdwenen is uit de semantiek van het werkwoord en een implicatuur is geworden. Zo'n soort ontwikkeling vindt misschien wel plaats in het Nederlands - getuige ook de opkomst van gaan als nieuw hulpwerkwoord van de toekomende tijd $^{11}$ - maar er is in het stuk van V\&B geen enkele reden te vinden om aan te nemen dat de ontwikkeling in (8) inmiddels voltooid is. In uitingen over de toekomst, zoals (la), is het onderscheid tussen de temporele en de modale lezing van zullen vaak niet goed te maken (zie paragraaf 2), en communicatief gezien meestal niet relevant; vanuit het diachrone perspectief in (8) ligt het bovendien voor de hand dat er gecombineerde temporeelmodale gevallen bestaan. De zuiver epistemisch-modale lezing zou beperkt kunnen zijn tot een relatief klein aantal constructies als zal wel en zou (wel eens, zomaar) kunnen, of, iets abstracter, tot de combinatie van zullen met een statisch werkwoord (inclusief hebben en zijn als hulpwerkwoord van de voltooide tijd of van aspect, zie (3)). ${ }^{12}$

Maar het bestaan van dat laatste type gevallen kan toch geen reden zijn om aan te nemen dat de temporele betekenis van zullen ook in alle andere constructies - en voor alle taalgebruikers, in alle regio's van het taalgebied (De Rooij 1985, 1986; Diepeveen, Boogaart, Brantjes et al. 2006), en in alle gebruikscontexten ${ }^{13}$ - volledig verdwenen is. Dat beweren V\&B niet expliciet en natuurlijk hoeft niet alle taalkundig onderzoek per se variatie-onderzoek te zijn, maar taalverandering brengt per definitie synchrone variatie met zich mee en elke analyse zal daar toch op z'n minst de ruimte voor moeten bieden. Doordat uit het model van V\&B, in hun eigen woorden, 'dwingend' volgt dat zullen niet eens temporeel kán zijn, wordt de indruk gewekt dat het nooit anders is geweest en dat

11 V\&B verzetten zich tegen het idee dat gaan een hulpwerkwoord van de toekomende tijd is en voor het huidige Standaardnederlands hebben ze daarin gelijk. Er zijn echter volop aanwijzingen dat het werkwoord zich wel in die richting ontwikkelt, zeker in het Belgisch Nederlands (De Rooij 1985, 1986; Van Bree 1997; Colleman 2000; Hilpert 2008; Van Olmen, Mortelmans \& Van der Auwera 2009). Daar wordt gaan nu ook epistemisch gebruikt, wat nog maar eens de nauwe band tussen de toekomstbetekenis en epistemische modaliteit onderstreept.

12 Zie Boogaart (2009a) voor een constructie-grammaticale opvatting van de semantiek van modale werkwoorden, en met name het werk van Hilpert (2008) over collocationele patronen met werkwoorden van 'toekomende tijd' in verschillende Germaanse talen.

13 Wie wel eens stukken van beginnende schrijvers, zoals studenten, nakijkt, weet dat die relatief veel zullen gebruiken, met name om de inhoud van hun stuk aan te kondigen. In hun eigen beleving is dat een puur temporeel gebruik, waarmee zij veel meer aangeven dan dat iets 'in hoge mate aannemelijk' is. 
het nooit anders zal ${ }^{14}$ zijn. Maar dat is aantoonbaar onjuist. Ter illustratie bespreek ik drie soorten gevallen waarin de temporele betekenis van zullen overheerst.

Als een conducteur de mededeling in (9) doet, dan mag de treinreiziger dat opvatten als een uiting waarin méér dan 'een bescheiden vorm van zekerheid' wordt uitgedrukt.

De trein naar Amsterdam zal vertrekken vanaf spoor 5.

Als de trein naar Amsterdam van een ander spoor blijkt te vertrekken, dan heeft de conducteur onwaarheid gesproken en kan hij daar op worden aangesproken (Colleman 2000:57). Er is ook een modaal gebruik van (9) denkbaar ('de trein naar Amsterdam vertrok gisteren vanaf spoor 5, dus dat zal nu ook wel weer zo zijn'), maar in die lezing verbindt de spreker zich niet aan de waarheid van de propositie en hij kan daarna rustig ontkennen dat hij een feitelijke mededeling over de toekomst heeft gedaan (Colleman 2000:63,nt7). Het gaat hier duidelijk om twee verschillende gebruikswijzen van zullen en het ligt voor de hand om de eerste dan (meer) temporeel te noemen.

Een andere context waarin de modale betekenis van zullen naar de achtergrond verdwijnt, is die waarin het gebruikt wordt in combinatie met een andere uitdrukking van epistemische modaliteit, zoals in (10b) t/m (10d).
a. Hij zal ziek zijn.
b. Het is 'in hoge mate aannemelijk' dat hij ziek zal zijn.
c. Hij lijkt/schijnt ziek te zullen zijn
d. Ik denk dat hij ziek zal zijn/Denk je dat hij ziek zal zijn?

Omdat het complement 'ziek zijn' een toestand is, ligt een epistemische lezing van zullen in (10a) voor de hand (vgl. (3a)). Maar in de andere zinnen in (10) is dat veel minder duidelijk; daar is een puur temporele lezing van zullen naar mijn gevoel prominenter. ${ }^{15}$ Dat is niet zo gek, aangezien de modale informatie in deze zinnen al door een ander element wordt geleverd, maar zo'n temporele interpretatie van het werkwoord moet dus wel beschikbaar zijn. In het geval van statische complementen als 'ziek zijn' komt daar bij dat zonder zullen, als in (11), deze zinnen min of meer automatisch als uitingen over het heden worden geïnterpreteerd.
a. Hij is ziek.
b. Het is 'in hoge mate aannemelijk' dat hij ziek is.
c. Hij lijkt/schijnt ziek te zijn.
d. Ik denk dat hij ziek is/Denk je dat hij ziek is?

Het is handig voor een spreker om te beschikken over een middel waarmee hij, als de context niet duidelijk genoeg is, expliciet aan kan geven dat een uiting op de toekomst

14 Dit gebruik van zal is een goed voorbeeld van een context waarin het, door het gebruik van nooit en de tegenstelling met is geweest, een pure toekomst-lezing krijgt.

15 In (10c) is dat het sterkst, mogelijk omdat zullen daar geen finiete vorm is en finietheid een voorwaarde lijkt te zijn voor de epistemische lezing (zie paragraaf 2). 
betrekking heeft. Gezien het verschil tussen de zinnen in (10) en (11) lijkt zullen die functie heel goed te kunnen vervullen.

Een laatste voorbeeld van het temporeel gebruik van zullen is te vinden in de dialoog in $(12)$.

(12) - Altijd die twijfel!

- Nu meer dan ooit. Ik kan niets. Ik heb nooit iets gekund.

- 'Ik zal nooit iets kunnen'! voltooide zij schertsend.

(Louis Couperus, 'Metamorfoze', De Gids 61 (1897), p. 246)

Hier is door de tegenstelling met ik kan niets (voor het heden) en ik heb nooit iets gekund (voor het verleden), voor $i k$ zal nooit iets kunnen moeilijk een andere interpretatie mogelijk dan een temporele. Het voorbeeld in (12) is wat gedateerd, maar vergelijkbare actuele gevallen als (13) zijn makkelijk te vinden.

(13) We waren gisteren goedkoper dan Albert Heijn, we zullen dat morgen zijn en we zullen dat ook blijven. (Het Parool, 10 september 2013)

De betekenisomschrijving die V\&B geven voor zullen is zo abstract dat de temporele lezing van het werkwoord in (9), (10), (12) en (13) er in principe best onder zou kunnen vallen, zoals bij Kirsner (1969). Of een generalisatie op zo'n hoog niveau van abstractie voor modale werkwoorden zinvol is, is zeer de vraag (Boogaart 2009a; Kirsner 2012:134), maar door het model van V\&B wordt de optie om de temporele lezing te beschouwen als een specifieke (sterke) vorm van 'aannemelijkheid' sowieso principieel uitgesloten. Als zij dat voor specifieke gebruikswijzen van zullen aan zouden nemen, wordt het moeilijk vol te houden dat in alle andere gevallen waarin een uiting met zullen (toevallig) over de toekomst gaat, zoals (la), de oudere temporele betekenis niet langer meeklinkt. ${ }^{16}$

\section{De modaliteit van zou(den)}

In de vorige paragraaf, over de temporele betekenis van zullen, ontbreken voorbeelden met een verleden tijd van het werkwoord. Dat betekent niet dat er helemaal geen gevallen van zou(den) bestaan die puur posterioriteit uitdrukken, maar ze zijn wel moeilijker te vinden dan bij de tegenwoordige tijd. Het type in (14), over Nelson Mandela, zou een voorbeeld kunnen zijn.

(14) Vier jaar later zou hij de eerste democratisch gekozen president van Zuid-Afrika worden.

(www.maandbladzuidafrika.nl)

16 Vgl. Bybee (2013: 65-66 en referenties), die voor het Engelse will laat zien dat de originele wens-betekenis van het werkwoord in bepaalde contexten en constructies behouden is. 
Er bestaat in (14) bij de spreker geen enkele twijfel over de vraag of en wanneer Nelson Mandela president van Zuid-Afrika is geworden. De gebeurtenis wordt met behulp van zou gepresenteerd vanuit een perspectief in het verleden: de dag, 11 februari 1990, dat Mandela de gevangenis verliet. Dat heeft een sterk dramatiserend effect omdat op die dag niemand kon weten wat er precies ging gebeuren, maar de spreker weet dat intussen heel goed, en zou lijkt hier, semantisch, niet veel meer te doen dan posterioriteit uitdrukken ten opzichte van die dag in $1990 .{ }^{17}$

Hoewel het gebruik van zou(den) meestal wel degelijk modaal is, levert de vorm toch problemen op voor de benadering van V\&B. Dat heeft dan niet zoveel te maken met hun modale karakterisering van zullen, maar wel met hun temporele karakterisering van PAST. Een illustratief voorbeeld is de laatste zin van de roman Strikt van Minke Douwesz (Van Oorschot, 2003), geciteerd in (12) (Boogaart 2012).

(12) En ik zou kunnen huilen, om mij, om ons, om alles wat komen ging.

De hele roman van 837 pagina's is geschreven in de verleden tijd. Voor de allerlaatste zin lijkt dat in eerste instantie ook te gelden, aangezien de vorm zou PAST is. Het interessante aan (12) is echter dat de verteller hier plotseling uit de coulissen stapt en als schrijver van het boek, op het 'schrijfmoment', aan het woord is. Het effect is hetzelfde als wanneer er een tegenwoordige tijd had gestaan zoals in (13).

(13) En ik kan wel huilen, om mij, om ons, om alles wat komen ging.

De zin met zou kunnen in (12) drukt, in de parafrase van V\&B, een 'bescheidener vorm van zekerheid' uit dan kan in (13), dus de vorm is duidelijk modaal en niet temporeel te interpreteren. Maar de situatie van 'kunnen huilen' wordt ook in (12) in een heden-domein gesitueerd en niet in een 'verleden domein'. Zou kunnen is, anders gezegd, een voorzichtige variant van kan (PRES) en niet van kon (PAST). Aangezien V\&B de noties PRES en PAST alleen in temporele termen definiëren, lijkt zo'n 'modaal' gebruik van PAST lastig in te passen in hun model.

Het voorbeeld in (12) valt op omdat het in de laatste zin van het boek een perspectiefwisseling met zich mee brengt van verleden naar heden, maar dit type modaal gebruik van zou(den), binnen het domein van het heden, is verre van uitzonderlijk. De vorm kan gebruikt worden om aan te geven dat een situatie alleen hypothetisch is of niet-werkelijk, als in (14), of om afstand tot de gesprekssituatie te creëren uit voorzichtigheid of beleefdheid, als in (15).

(14) Als ik Marie was, dan zou ik nú een afspraak met hem maken.

(15) Ik zou eigenlijk wel een afspraakje met Marie willen maken.

17 V\&B suggereren dat de spreker in zo'n geval de voltooid tegenwoordige tijd had moeten gebruiken en dat de zin daarom als 'counterfactual' zal worden geïnterpreteerd, maar dat is hier duidelijk niet aan de orde. In het algemeen kunnen zou(den)-vormen heel goed gebruikt worden om het perspectief op een punt (bij een personage) in het verleden te laten, los van de kennis van de spreker in het heden. 
Veelal betreft het contexten waarin andere talen - en een oudere taalfase van het Nederlands - een vorm van de subjunctief/conjunctief zouden gebruiken. ${ }^{18}$ Het gaat hier steeds om standen van zaken die op het spreekmoment niet-werkelijk of potentieel zijn, of toch zo worden voorgesteld, en niet om standen van zaken die in een temporeel domein in het verleden gelokaliseerd moeten worden (ten opzichte van een virtueel punt $n^{\prime}$ ).

Het is de vraag of dit soort gevallen in het model van V\&B ingepast kunnen worden. Een voor de hand liggende mogelijkheid is om de semantiek van tempus zodanig te verruimen dat ook niet-temporele gebruikswijzen eronder vallen. De vorm zou(den) draagt dan wel het kenmerk PAST, maar de betekenis daarvan zou zo abstract moeten zijn dat niet alleen temporele afstand maar ook andersoortige afstand tot de gesprekssituatie er compatibel mee is (Janssen 1989b). De keuze tussen PRES en PAST is in deze opvatting ook zelf al een kwestie van epistemische modaliteit (zie Brisard \& Patard 2011 en referenties aldaar). Wat voor deze oplossing pleit is dat zo'n 'modale' lezing van PAST zeker niet beperkt is tot zou(den) maar dat ook de onvoltooid verleden tijd van andere werkwoorden in dit type contexten gebruikt kan worden, zoals al blijkt uit het gebruik van was in de bijzin van (14). Maar ook in de hoofdzin kan de spreker daar een vorm zonder zou gebruiken, zie (16).

(16) Als ik Marie was, dan maakte ik nú een afspraak met hem.

(17) Ik wou eigenlijk wel een afspraakje met Marie maken.

In tegenstelling tot zou willen in (15), kan de vorm wou in (17) betrekking hebben op een wens in het verleden, maar het kan, net als (15), ook een voorzichtige formulering zijn van een wens van de spreker op het moment van spreken. Dat de verleden tijd in het Nederlands op deze manier modaal gebruikt kan worden, is bekend, maar het vormt onmiskenbaar een probleem voor de definitie van het kenmerk PAST bij V\&B. Het probleem is niet beperkt tot zou(den), maar is bij die vorm wel het meest manifest. Je kunt je afvragen in hoeverre zou(den) in bepaalde constructies, bijvoorbeeld in combinatie met een ander modaal werkwoord (zou kunnen/moeten/willen/mogen), überhaupt nog semantisch als PAST van zullen kan worden beschouwd.

\section{Tot besluit}

Volgens V\&B wordt posterioriteit in het Nederlands uitgedrukt door PRES en PAST, ook in zinnen die een vorm van het werkwoord zullen bevatten. De temporele informatie van PRES en PAST is namelijk vaag en omvat ook een niet-geactualiseerd deel van het heden, respectievelijk het verleden. De betekenisbijdrage van zullen is niet temporeel, maar altijd epistemisch-modaal ('het is in hoge mate aannemelijk dat...'). In het voorafgaande heb ik drie problemen van deze analyse behandeld, die ik hier nog even kort samenvat.

18 We betreden hier dus het domein van wat traditioneel mood wordt genoemd, ter onderscheiding van modality in het algemeen. Voor het Nederlands is dat onderscheid wel lastig te maken aangezien mood hier onder andere wordt uitgedrukt met behulp van modale werkwoorden als zou(den) en moge, en partikels, of simpelweg met de verleden tijd (Roels, Mortelmans \& Van der Auwera 2007; Boogaart \& Janssen 2010). 
1. De epistemische interpretatie van modale werkwoorden, inclusief die van zullen, is niet inherent aan de lexicale betekenis van het werkwoord, maar komt tot stand door een samenspel van verschillende factoren, waaronder finietheid en (tegenwoordige) tijd, en aspectuele eigenschappen van het complement. In de epistemische lezing is de bijdrage van tempus niet vaag: de finiete vorm van zullen koppelt de modale evaluatie aan de gesprekssituatie, met name aan de spreker en het spreekmoment. De notie heden-domein bij V\&B is te globaal om dit cruciale aspect van finiete tempusvormen en epistemische modale werkwoorden te beschrijven.

2. Het idee dat het werkwoord zullen nooit posterioriteit uitdrukt is moeilijk te verenigen met het feit dat de epistemische lezing, diachroon gezien, ontstaan is uit de toekomstlezing en dat die twee lezingen ook in het hedendaagse taalgebruik vaak moeilijk van elkaar te scheiden zijn; in een aantal contexten en constructies overheerst bovendien de temporele lezing. De zuiver epistemische lezing van zullen, die niet de toekomst betreft, is beperkt tot een aantal specifieke constructies - vooral die met een statisch complement - en wordt vaak ondersteund met een modaal partikel. Die beperkingen zijn niet goed te verklaren als epistemische modaliteit inherent is aan de semantiek van zullen.

3. Behalve zullen kan ook tempus door sprekers modaal gebruikt worden. Dat is het duidelijkst voor de verleden tijd: de spreker kan daarmee situaties presenteren die mogelijk of onwerkelijk zijn op het moment van spreken, en niet op (of ten opzichte van) een moment in het verleden. Dat soort gevallen vormt een probleem voor de strikt temporele definitie die V\&B geven van de tegenstelling tussen PRES en PAST, en met name voor hun analyse van de verleden tijd van zullen, die vaak in dit type contexten wordt gebruikt. Nu V\&B eenmaal hebben geaccepteerd dat zullen geen hulpwerkwoord van tijd is, vraag ik me af of zij op grond van een vergelijkbare redenering niet tot de conclusie moeten komen dat ook de betekenisbijdrage van PRES en PAST niet principieel temporeel hoeft te zijn.

Algemener blijkt op alle drie deze punten dat temporaliteit en modaliteit heel lastig van elkaar te onderscheiden zijn en dat de werkelijkheid van het taalgebruik zich niet laat vangen in een systeem van binaire opposities. De grote vraag is natuurlijk waarom je dat eigenlijk zou willen. 


\section{Temporaliteit én modaliteit: een repliek}

\section{Abstract}

This reply addresses Ronny Boogaart's comments on our contribution Temporaliteit en modaliteit. A general problem with these comments is that Boogaart does not seem to appreciate that we make a strict distinction between semantics (the meaning of the sentence) and pragmatics (the use of the sentence in a given context). The former determines the situations in which a given sentence is true, whereas the latter determines a subset of these situations that are 'intended' by the speaker. The central role we attribute to pragmatics in determining the actual location of the eventuality in the relevant present/past tense domain immediately refutes RB's claim that we do not explicitly refer to contextual factors.

Net als andere modale werkwoorden levert zullen een specifieke bijdrage aan de zinsbetekenis.

Herziene editie van het WNT (2066)

\section{$1 \quad$ Inleiding}

In deze repliek op het commentaar van Ronny Boogaart (voortaan: RB) op onze bijdrage Temporaliteit en modaliteit zullen wij proberen een aantal misverstanden uit de weg te ruimen om zo dichter te komen bij de doelstelling die we ons gesteld hadden voor het Antwerpse colloquium, namelijk te laten zien dat semantiek niet kan zonder een solide formele basis en een grote mate van precisie. Het is echter duidelijk dat betekenis van een zin $\mathrm{Z}$ niet gelijk gesteld kan worden aan de interpretatie van $\mathrm{Z}$ en onze bijdrage beoogde dan ook te illustreren hoe de informatietoestand van de spreker en de hoorder kan leiden tot een nader ingeperkte lezing van Z. Het feit dat we daarbij cruciaal gebruik maken van Grice' coöperatieve principe laat onmiddellijk zien dat RB's enige malen herhaalde stelling dat wij niet expliciet verwijzen naar de gesprekssituatie niet houdbaar is.

In onze reactie op de drie door RB aangevoerde hoofdpunten willen we dan ook strikt een scheiding blijven maken tussen semantiek, pragmatiek en de andere modules van de 
grammatica zoals de syntaxis. Als RB spreekt over de mogelijkheid dat "het complement van zullen een toestand is, zoals '(ziek) zijn'" of dat dit "complement een gebeurtenis is, zoals 'een afspraak maken"', dan is voor vrijwel elke syntacticus te begrijpen wat er bedoeld wordt. Vanuit het perspectief van de formele semantiek (zoals ingenomen in V\&B) heeft zullen echter geen complement: het wordt behandeld als een operator die als functie werkt op een tempusloze predicatie om een tempusloze predicatie te vormen.

Bovendien is het zeer de vraag of 'een afspraak maken' zinvol een gebeurtenis kan worden genoemd omdat eerst de vraag moet worden gesteld of een gebeurtenis iets is met tempus of zonder tempus en daarna de vraag of een infinitiefconstructie een gebeurtenis kan zijn. Het kost minstens een halve pagina om de uitspraak ter plekke te corrigeren en te laten zien wat er in V\&B echt staat. Dat doen we dus niet, maar we raden de lezer aan om RB niet blindelings te volgen in zijn weergave van wat er in V\&B staat, hoe gemakkelijk zijn tekst misschien ook leest. We zullen de voornaamste onheilsplekken in onze repliek betrekken. We verwijzen rechtstreeks terug naar zinnen in RB's commentaar zonder ze opnieuw te nummeren en we gebruiken dezelfde paragraaftitels.

\section{De rol van finietheid en de gesprekssituatie}

Verkuyl (2008) heeft bij de modernisering van Te Winkels binaire systeem radicaal gebroken met het identificeren van het spreekmoment $S$ of $n$ met het Heden als grens tussen Verleden en Toekomst. Die identificatie is vanzelfsprekend in een ternair systeem maar onnatuurlijk in een binair systeem, want juist door de cognitieve basis voor de binaire opposities in Te Winkels systeem is duidelijk dat het gebruik van een tegenwoordige of verleden tijdsvorm informatie geeft over hoe sprekers vorm geven aan wat zij te zeggen hebben. Het onderliggende idee is dat door contextuele informatie spreker en hoorder ervan uitgaan dat er een hedendomein $i$ of verledendomein $i$ ' is waarin gebeurens ten opzichte van elkaar kunnen worden gepositioneerd tijdens een zich ontwikkelend discours; zie de bespreking van het geconstrueerde tekstfragment (6) in onze bijdrage.

De keuze tussen het gebruik van de operatoren PRES of PAST is daarmee een presentatiekeuze. Kenmerk van een discours in de tegenwoordige tijd is dat het vliedende punt $n$ meegaat tijdens het spreken maar ook gewoon doorloopt in de stiltes die er kunnen vallen tijdens een gesprek. Er is geen enkele reden om dit punt $n$ heden te noemen of te eisen dat het samenvalt met één specifiek spreekmoment: het is voldoende om aan te geven dat het zich ergens in het hedendomein bevindt (en niet in het verledendomein): dit is wat uitgedrukt wordt door onze definitie van het hedendomein $i$ o $n$. De functie van $n$ in een binair systeem is om de steeds veranderende scheiding aan te geven tussen wat inmiddels geactualiseerd is in het hedendomein en wat daarin nog geactualiseerd moet worden, deo volente zeggen we er maar metaforisch bij. Uit dit alles volgt dat RB's Figuur 1 absoluut niet klopt als weergave van de semantische representatie die door V\&B worden voorgesteld. RB kijkt met de bril van Janssen (1989a) en die bril vervormt nogal, en die vervorming neem nogal dramatische vormen aan in het geval van de figuren 2 en 3, die drastisch verschillen van wat wij voorstellen of wenselijk achten.

Bovengenoemde vervorming lijkt in eerste instantie tamelijk onschuldig in het geval van RB's Figuur 1, maar schijn bedriegt. RB gebruikt Figuur 1 om twee problemen voor 
V\&B te signaleren. Het eerste probleem is dat er geen duidelijk onderscheid gemaakt wordt tussen de interpretatie van finiete en niet-finiete vormen van het werkwoord in (la) Marie zal een afspraak met hem maken en (2) Marie maakt een afspraak met hem. Dit is wellicht een probleem voor de representatie in Figuur 1, maar binnen het Binary Tense kader is dit een pseudo-probleem. De semantische representatie van (la) is PRES(ZULLEN(Marie een afspraak maken)) en die van (2) PRES(Marie een afspraak maken) en deze representaties laten geen twijfel over de semantische overeenkomsten en verschillen tussen deze twee zinnen. Belangrijk is dat de morfologische realisatie van PRES (als inflectie op zullen of het hoofdwerkwoord maken) niet van invloed is op zijn bijdrage aan de betekenis van de zin: in beide gevallen maakt PRES het mogelijk om de afspraak van Marie zo te positioneren dat $n$ er deel van uitmaakt maar ook zo dat de afspraak in het niet-geactualiseerde deel van $i$ wordt geplaatst. Dat zijn geen aparte lezingen: PRES is essentieel onderinformerend, zoals in V\&B uiteengezet. Het tweede probleem zou zijn dat binnen het Binary Tense kader niet expliciet verwezen wordt naar de gesprekssituatie, maar dit probleem bestaat helemaal niet: de karakterisering $i$ o $n$ introduceert de gesprekssituatie doordat het vliedende punt $n$ er deel van uitmaakt en doordat de lokalisering van de verschillende gebeurens binnen het hedendomein $i$ wordt bepaald door de informatie aangeleverd door nieuwe zinnen in het discours. Het is dan ook onjuist te stellen (als in RB's Figuur 1) dat de informatie bevat in de vorm zal een afspraak maken als geheel temporeel gelokaliseerd wordt: dat kan niet omdat PRES opereert op de output van de operatie die ZULLEN uitvoert op de tempusloze predicatie. Wat temporeel gelokaliseerd wordt is slechts het gebeuren een afspraak maken.

Vlak voor zijn Figuur 2 schrijft RB over V\&B: "Hun analyse van samengestelde vormen als zullen+infinitief - en overigens ook van hebben/zijn+voltooid deelwoord - kan wel compositioneel genoemd worden, maar niet op dezelfde manier als die van Janssen (1989a): in tegenstelling tot Janssen, beschouwen V\&B zal in (la) niet als de aanduiding van een situatie die in principe los van de situatie in het complement in de tijd gelokaliseerd kan worden". Dit klopt en hier wreekt zich nu precies het niet-formele karakter van Janssens benadering (overigens niet ongewoon in cognitief-linguïstische kringen): wat betekent het als zullen refereert aan een situatie of een situatie aanduidt? En wat betekent het als zullen los van een andere situatie gelokaliseerd wordt? Het zijn loze bewoordingen die ook niet met plaatjes kunnen worden aangevuld, want Figuur 2 vult de tekst niet aan en is zeker niet compositioneel in de gebruikelijke zin van het woord dat de betekenis van een syntactische eenheid afgeleid is van de betekenis van zijn samenstellende delen.

Ondanks dat wij RB's Figuur 2 afwijzen als semantische representatie van (la) sluiten wij ons wel aan bij de tweede zin van de direct op dit figuur volgende tekst: "De modale evaluatie van het maken van de afspraak als 'in hoge mate aannemelijk' gebeurt namelijk door de spreker op het spreekmoment, op grond van de informatie waarover hij in de gesprekssituatie beschikt." Precies, maar omdat deze interpretatie afhankelijk is van de informatie waarover de spreker in de gesprekssituatie beschikt is hier geen sprake van semantiek (als onderdeel van de competence) maar van pragmatiek (als onderdeel van de performance). De onzekerheid uitgedrukt door een zin als Ze zal wel een afspraak hebben is precies hetzelfde in het geval de spreker Marie de kamer van de directeur ziet binnengaan of in het geval de spreker vertelt dat ze de directeur die middag wil zien. Zal duidt hier geen situatie aan, maar levert slechts een slag om de arm. 
Het is in het binaire systeem daarom ook absoluut uitgesloten dat (6b) Het is morgen in hoge mate aannemelijk dat Marie een afspraak met hem maakt een juiste parafrase is van zin (5) Marie zal morgen een afspraak met hem maken: modaliteit is afhankelijk van de kennistoestand van de spreker en niet van de tijd en kan daarom ook niet gemodificeerd worden door een tijdsbepaling. In (5) geeft het adverbium nadere informatie over het heden $j$ van het gebeuren 'een afspraak met hem maken' en de enige juiste parafrase van (5) is derhalve die in (6a) waarin het adverbium in dezelfde deelzin staat als de woordgroep die dat gebeuren uitdrukt: Het is in hoge mate aannemelijk dat Marie morgen een afspraak met hem maakt.

RB schrijft: "De tijd van een afspraak maken wordt in (la) bepaald door de relatie met de tijd van zal: dat kan een relatie van posterioriteit zijn, zoals in (la) voor de hand ligt, of van gelijktijdigheid, zoals bij de zinnen in (3)". Dit citaat laat zien dat hem blijkbaar ontgaan is dat het begrip 'de tijd van zal' in een binair systeem niet als zodanig bestaat: RB verwart hier de syntactische/morfologische categorie persoonsvorm met een of andere semantische categorie. In de infinitiefvorm van zullen is de door RB geforceerde tegenstelling tussen posterioriteit "zoals in (la)" en gelijktijdigheid "zoals in (3)" semantisch helemaal niet aanwezig. Positionering van het gebeuren is toevertrouwd aan PRES en PAST en adverbiale bepalingen van tijd zoals morgen in de hierboven besproken zin (5).

We ronden dit punt af, al valt er per alinea veel aan te merken op de weergave door RB van wat er in V\&B gesteld wordt. Dat kan komen door onduidelijkheid in onze bijdrage, maar het kan ook komen door RB's neiging om eigen theoretische termen mee te nemen in de beoordeling. Zo heldert bijvoorbeeld ook de uitbreiding naar het werk van Langacker weinig op behalve dan dat de term Heden zou moeten worden ingeruild voor Ground, maar het is niet goed te zien wat dat oplost met onduidelijke noties als 'speech event', 'immediate circumstances', etc. De notie 'Heden' die figureert in V\&B is wezenlijk een discoursnotie waarin $n$ voortgaat van zin tot zin van sprekers en hoorders (met stiltes en al) en waarin uiteindelijk pragmatisch bepaald wordt welke beperkingen er worden opgelegd aan interpretaties van zinnen. Het zal daarom duidelijk zijn dat wij alle passages waarin RB ons verwijt dat de gesprekssituatie niet in acht nemen als onjuist verwerpen.

\section{De temporaliteit van zullen}

In zijn bewondering voor het WNT verzuimt RB te bedenken dat bij de beschrijving van het woord zal in zinnen van het Nederlands, zoals in zoveel analyses uit het Neerlandistische verleden, niet de moeite is genomen zal te zien als pres+zullen en daaruit dan de consequenties te trekken. Wat is het verschil tussen PRES+zullen in (la) Marie zal een afspraak met hem maken en PRES+moeten in Marie moet een afspraak met hem maken? Beide zinnen zijn op dezelfde wijze onderinformerend over de precieze positionering van de afspraak. Er is voor de interpretatie van de moet-zin geen enkel verschil met de hierboven geschetste situatie waarin (la) gezegd werd op het moment van binnengaan van Marie in de kamer van haar baas en de andere situatie waarin de spreker van Marie weet dat ze die middag nog naar haar baas gaat. Dat kan alleen maar verantwoord worden door aan te nemen dat de operator PRES hier die beide mogelijkheden openlaat, ongeacht het modale hulpwerkwoord waarmee hij optreedt. 
We merken dit op omdat RB zich beroept op historische studies waarin een ontwikkeling wordt waargenomen in de semantische betekenis van zullen, die zichtbaar wordt gemaakt in (8). Maar de autoriteit van die studies lijdt onder het feit dat ze dezelfde tekortkomingen vertonen als die welke we hierboven hebben besproken. Als auteur X tot de constatering komt dat zullen op een bepaald moment toekomst uitdrukt, is die stellingname gekleurd door zijn of haar eigen visie op de notie van toekomst: is het een theoretische linguïstische notie of een informele ontologische? Zou auteur $\mathrm{X}$ al of niet post mortem de theoretische term 'verwachting van de spreker' hebben gebruikt in plaats van de term 'toekomst' als hij of zij de beschikking had gehad over de binaire kijk op het tempussysteem? Pas bij herijking van de historische studies in termen van een binaire analyse, kunnen vanuit de historische hoek argumenten voor of tegen de temporaliteit van zullen worden aangevoerd. ${ }^{11}$

In zijn bespreking van zin (9) De trein naar Amsterdam zal vertrekken vanaf spoor 5 onderscheidt RB een temporele lezing (als de trein vanaf spoor 7 wegrijdt, is er verkeerd omgeroepen) van een modale lezing (ik veronderstel dat de trein vanaf spoor 5 vertrekt). Deze twee "lezingen" hebben echter niets met de betekenis van zin (9) te maken, maar met het verwachtingspatroon van de hoorder. Als de hoorder denkt dat de omroeper volledig geïnformeerd is (of zou moeten zijn), dan krijgen we de eerste gebruikswijze. Als de hoorder redenen heeft om aan te nemen dat de aangesproken persoon niet volledig geïnformeerd is, dan krijgen we de tweede gebruikswijze. Alleen al ons gebruik van de term gebruikswijze maakt duidelijk dat we naar onze mening niet te maken hebben met semantiek maar met pragmatiek (Grice' coöperatieve principe). Hier wreekt zich weer dat RB daar geen onderscheid tussen wenst te maken.

Over een (nogal onnatuurlijke) zin als (10b) Het is 'in hoge mate aannemelijk' dat hij ziek zal zijn zegt RB dat daar een "puur temporele lezing ... prominenter" is. Volgens hem zit de aannemelijkheid in de hoofdzin zodat zal niet nog een keer aannemelijkheid kan uitdrukken. Binnen ons voorstel is dat niet anders: het coöperatieve principe van Grice werkt hier door redundantie uit te sluiten en dat kan door het gebeuren 'ziek zijn' te positioneren in het niet-geactualiseerde deel van $i$. Dat hier sprake is van pragmatiek is duidelijk uit het feit dat zo'n 'toekomst'-interpretatie eenvoudig geblokkeerd kan worden. De zin Het is in hoge mate aannemelijk dat hij inmiddels ziek zal zijn vereist een lezing waarin het gebeuren gesitueerd is rondom $n$. Merk op dat (10b) evenmin een 'toekomst'-lezing hoeft te hebben als hij gaat over iemand die er om bekend staat dat hij met smoezen komt: "De telefoon gaat: het is Jan. Het is in hoge mate aannemelijk dat hij ziek zal zijn". We vinden dus ook in (10b) de bekende onderinformatie van PRES in zal.

Het Couperus-voorbeeld in (12) kan eveneens volledig pragmatisch worden verklaard: Hélène concludeert al grappend dat de door Aylva verstrekte informatie over het heden en

1 Een bijkomend punt is dat het WNT het temporele gebruik van zullen beschrijft met behulp van de notie 'toekomstverwachting': "Zullen plaatst de werking vanaf een referentiepunt in de toekomst. De temporeele functie overheerscht; de toekomstverwachting wordt als zekerheid beleefd. Soms is ook een modaal bet. -aspect aanwezig." Het verdient benadrukt te worden dat de temporele functie van zullen in epistemische termen wordt beschreven: de toekomstverwachting wordt als zekerheid beleefd. Dit alleen is naar onze mening al ruim voldoende om de nodige vraagtekens bij de notie "temporele functie" te plaatsen. We zullen ons verder niet bezighouden met de vraag wat de juiste exegese van het WNT is. 
het verleden (hij kan niets en heeft ook nooit iets gekund) een redelijke grond is voor de conclusie dat ook in de voor hen toegankelijke mogelijke werelden niets kan.

\section{De modaliteit van zou(den)}

In deze paragraaf snijdt RB twee verschillende kwesties aan. De eerste betreft zinnen als (14) Vier jaar later zou hij de eerste democratisch gekozen president van Zuid-Afrika worden. Zinnen als deze worden vaak aangevoerd als argument om temporele van modale gebruikswijzen van zullen te onderscheiden. RB zegt hierover:

“De gebeurtenis wordt met behulp van zou gepresenteerd vanuit een perspectief in het verleden: de dag, 11 februari 1990, dat Mandela de gevangenis verliet. Dat heeft een sterk dramatiserend effect omdat op die dag niemand kon weten wat er precies ging gebeuren, maar de spreker weet dat intussen heel goed, en zou lijkt hier, semantisch, niet veel meer te doen dan posterioriteit uitdrukken ten opzichte van die dag in 1990."

De vraag die ook gesteld had moeten worden is: Wat is het verschil met (14') Vier jaar later werd hij de eerste democratisch gekozen president van Zuid-Afrika? Het feit dat (14') minstens zo stellig is over wat er gebeurde als (14) laat zien dat zullen helemaal niet nodig is om posterioriteit uit de te drukken. Het verschil zit hem in de modale informatie: het modale perspectief dat in (14) door het gebruik van zullen wordt bijgedragen, krijgt in (14') de vorm van absolute zekerheid aan de kant van de spreker. In (14") Hij zou de eerste democratisch gekozen president van Zuid-Afrika worden verklaart de afwezigheid van de tijdsbepaling waarom het gebeuren hier wel zowel rondom $n^{\prime}$ als in het nog niet geactualiseerde deel van $i^{\prime}$ gepositioneerd kan wordem. De aanwezigheid van de adverbiale bepaling in (14) introduceert een factor die de onderinformatie van PRES en PAST in (14") teniet doet.

De tweede kwestie betreft de vraag of V\&B het modale gebruik van zullen wel kunnen verantwoorden. RB zegt van een zin als (12) En ik zou kunnen huilen, om mij, om ons, om alles wat komen ging: "Maar de situatie van 'kunnen huilen' wordt ook in (12) in een hedendomein gesitueerd en niet in een 'verleden domein'. Zou kunnen is, anders gezegd, een voorzichtige variant van kan (PRES) en niet van kon (PAST). Aangezien V\&B de noties PRES en PAST alleen in temporele termen definiëren, lijkt zo' $n$ 'modaal' gebruik van PAST lastig in te passen in hun model". Opvallend is dat RB hier niet PRES stelt tegenover PAST, maar de aanwezigheid van zou stelt tegenover de afwezigheid ervan in een zin met een presensvorm. Wat wordt hier vergeleken? Het is ons niet duidelijk. Wel is duidelijk dat het wat lastig is om zou in (12) en (15) te vervangen door zal, naar onze mening ook door de aanwezigheid van $i k$, want dezelfde zinnen met $h i j$ op de plaats van $i k$ worden de zinnen meteen begrijpelijker. Het gebruik van de verleden tijdsvorm in (12) en (15) is te duiden als een signaal van de spreker dat hij al eerder de mogelijkheid zag tot huilen of tot het maken van een afspraak. Het is bepaald niet nodig "de semantiek van tempus zodanig te verruimen dat ook niet-temporele gebruikswijzen eronder vallen". 
In voetnoot 18 suggereert RB op grond van paragraaf 4 in V\&B dat wij voorspellen dat zinnen met de verleden tijdsvorm van een epistemisch modaal werkwoord (inclusief $z u l$ len) altijd geïnterpreteerd moeten worden als counterfactuals. Dit is inderdaad een mogelijke lezing voor onze zinnen in (11), maar zoals we reeds aan het slot van de betreffende paragraaf aangaven kunnen er natuurlijk allerlei contextuele factoren zijn die uiteindelijk leiden tot een andere lezing. Eén zo'n factor is bijvoorbeeld de aanwezigheid van een alwetende verteller als in het geval van de hierboven besproken zin (14) Vier jaar later zou hij de eerste democratisch gekozen president van Zuid-Afrika worden, die een lezing als counterfactual uitsluit. We pretenderen niet dat wij al deze factoren al in kaart gebracht hebben: op dit moment kan ons voorstel beter gezien worden als een interdisciplinair onderzoeksprogramma, waaraan tenminste taalkundige subdisciplines als semantiek, pragmatiek en syntaxis een belangrijke bijdrage kunnen en moeten leveren.

\section{Tot besluit}

1. De epistemische interpretatie van modale werkwoorden, inclusief die van zullen, is inherent aan de lexicale betekenis van het werkwoord zelf en heeft niets van doen met de betekenis van PRES en PAST: vanuit semantisch perspectief is er sprake van temporaliteit én modaliteit.

2. De beschrijving van de historische ontwikkeling van zullen zal eerst ontdaan moeten worden van 'semantisch vuil' in de vorm van onbruikbare want niet-theoretisch gedefinieerde termen. De term toekomend is een handige, maar pretheoretische term die aansluit op onze behoefte om over de toekomst te spreken, ook al bedoelen we met het woord toekomst in feite het niet-geactualiseerde heden. Sprekers van natuurlijke taal zijn veel vrijer in hun gebruik van woorden als heden, verleden en toekomst dan taalkundigen, die moeten onderzoeken hoe natuurlijke taal feitelijk wordt gebruikt als ze zien dat het tempussysteem binair werkt.

3. Behalve zullen kan ook tempus door sprekers modaal gebruikt worden. Dat is het duidelijkst voor de tegenwoordige tijd in zinnen als Morgen vergader ik in New York. In de verleden tijdsvorm van zullen ligt de modaliteit (net als bij PRES) als vanzelfsprekend bij PAST, waarbij zullen de verdere modale kleuring voor zijn rekening neemt. Grice' coöperatieve principe is verantwoordelijk voor het optreden van bepaalde speciale effecten in de verleden tijd: het optreden van counterfactual lezingen is hier slechts één voorbeeld van.

4. Onderzoek naar de gebruikswijzen van temporele vormen vereist subdisciplinair onderzoek waarin tenminste de semantiek, de pragmatiek en de syntaxis/morfologie een gelijkwaardige rol dienen te spelen. Het op één hoop gooien van de relevante semantische, pragmatische en syntactische/morfologische aspecten, zoals naar onze mening te vaak gebeurt in RB's commentaar op onze bijdrage, is niet inzichtgevend en dient vermeden te worden. 


\section{Bibliografie}

Abraham, Werner (2001). Modals: toward explaining the 'epistemic non-finiteness gap'. In: Reimar Müller \& Marga Reis (red.), Modalität und Modalverben in Deutschen. Hamburg: Helmut Buske Verlag, pp. 7-36.

Bilderdijk, Willem (1826). Nederlandsche Spraakleer. 's Gravenhage: J. Immerzeel Jr.

Boogaart, Ronny (2007). The past and perfect of epistemic modals. In: Louis de Saussure, Jacques Moeschler \& Geneveva Puskas (red.), Recent advances in the syntax and semantics of tense, mood and aspect. Berlin: Mouton de Gruyter, pp. 47-70.

Boogaart, Ronny (2009a). Semantics and pragmatics in construction grammar: the case of modal verbs. In: Alexander Bergs \& Gabriele Diewald (red.), Contexts and constructions. Amsterdam/Philadelphia: John Benjamins, pp. 213-241.

Boogaart, Ronny (2009b). Een retorische straks-constructie. In: Ronny Boogaart, Josien Lalleman, Marijke Mooijaart \& Marijke van der Wal (red.), Woorden Wisselen. Voor Ariane van Santen bij haar afscheid van de Leidse universiteit. Leiden: Stichting Neerlandistiek Leiden, pp. 167-182.

Boogaart, Ronny (2012). Andere Tijden. Vaktaal, tijdschrift van de landelijke vereniging van neerlandici 25 (4), 16-18.

Boogaart, Ronny $\boldsymbol{\sigma}$ Theo A.J.M. Janssen (2010). Mood in Dutch. In: Björn Rothstein $\&$ Rolf Thieroff (red.), Mood in the languages of Europe. Amsterdam/Philadelphia: John Benjamins, pp. 117-132.

Boogaart, Ronny \& Radoslava Trnavac (2011). Imperfective aspect and epistemic modality. In: Adeline Patard \& Frank Brisard (red.), Cognitive approaches to tense, aspect, and epistemic modality. Amsterdam/Philadelphia: John Benjamins, pp. 217 248.

Boogaart, Ronny $\boldsymbol{\&}$ Egbert Fortuin (te versch.). Mood and modality in Cognitive Linguistics and Construction Grammar. In: Jan Nuyts \& Johan van der Auwera (red.), The Oxford Handbook of Mood and Modality. Oxford: Oxford University Press.

Bree, Cor van (1997). Wat is er met 'gaan' aan de hand? In: Mededelingenblad Oudgermanisten Vereniging, speciaal nummer Leven in de Oudgermanistiek, 72-77.

Brisard, Frank \& Adeline Patard (2011). Introduction. In: Adeline Patard \& Frank Brisard (red.), Cognitive approaches to tense, aspect, and epistemic modality. Amsterdam/ Philadelphia: John Benjamins, pp.1-17.

Broekhuis, Hans \& Norbert Corver (2014). Syntax of Dutch. Verbs and verb phrases, volume 1. Amsterdam: Amsterdam University Press (in voorbereiding).

Broekhuis, Hans \& Henk J. Verkuyl (2014). Binary tense and modality. Natural Language and Linguistic Theory (te verschijnen). 
Bybee, Joan L. (2013). Usage-based theory and exemplar representations of constructions. In: Thomas Hoffmann \& Graeme Trousdale (red.), The Oxford Handbook of Construction Grammar. Oxford: Oxford University Press, pp. 49-69.

Byloo, Pieter \& Jan Nuyts (2012). Meaning change in the Dutch core modals: (Inter) subjectification in a grammatical paradigm. Acta Linguistica Hafniensia 44 (in druk).

Colleman, Timothy (2000). Zullen, gaan of presens? Een verkennend corpusonderzoek naar de toekomstaanduiders in het (Belgische) Nederlands. In: Magda Devos, Veronique De Tier \& Jacques Van Keymeulen (red.), Nochtans was scherp van zin. Een bundel artikelen aangeboden aan Hugo Ryckeboer voor zijn 65ste verjaardag. Gent: Vakgroep Nederlandse taalkunde, pp. 51-64.

Condoravdi, Cleo (2002). Temporal interpretation of modals: Modals for the present and for the past. In: David Beaver et al. (red.), The construction of meaning. Stanford: CSLI Publications, pp. 59-88.

Diepeveen, Janneke, Ronny Boogaart, Jenneke Brantjes, Pieter Byloo, Theo Janssen \& Jan Nuyts (2006). Modale uitdrukkingen in Belgisch-Nederlands en Nederlands-Nederlands: corpusonderzoek en enquête. Amsterdam/Münster: Stichting Neerlandistiek VU/Nodus Publikationen.

Droste, Frederik G. (1956). Moeten. Een structureel semantische studie. Groningen: J.B. Wolters.

Droste, Frederik G. (1958). Het temporele in het moderne Nederlands. De Nieuwe Taalgids $51,305-312$.

Duinhoven, A.M. (1994). Over modaliteit gesproken. De Nieuwe Taalgids 87, 30-56.

Ebeling, Carl L. (1962). A semantic analysis of the Dutch tenses. Lingua 11, 86-99.

Ebeling, Carl L. (2006). Semiotaxis. Over theoretische en Nederlandse syntaxis. Amsterdam: Amsterdam University Press.

Eide, Kristin M. (2011). Modals and the present perfect. In: Tanja Mortelmans, Jesse Mortelmans \& Walter de Mulder (red.), In the mood for mood (Cahiers Chronos 23). Amsterdam/New York: Rodopi, pp. 1-20.

Foolen, Ad \& Helen de Hoop (2009). Conflicting constraints on the interpretation of modal auxiliaries. In: Lotte Hogeweg, Helen de Hoop \& Andrej Malchukov (red.), Cross-linguistic semantics of tense, aspect, and modality. Amsterdam: John Benjamins, pp. 303-316.

Fritz, Gerd (1997). Historische Semantik der Modalverben. Problemskizze - Exemplarischen Analysen - Forschungsüberblik. In: Gerd Fritz \& Thomas Gloning (red.), Untersuchungen zur semantischen Entwicklungsgeschichte der Modalverben im Deutschen. Tübingen: Niemeyer, pp. 1-157.

Grice, H. Paul (1975). Logic and conversation. In: P. Cole \& J. L. Morgan (red.), Syntax and Semantics 3: Speech Acts. San Diego, CA: Academic Press, pp. 41-58.

Grice, H. Paul (1989). Studies in the Way of Words. Cambridge, MA: Harvard University Press.

Haeseryn, Walter, e.a. (1997). Algemene Nederlandse Spraakkunst. Groningen/Deurne: Martinus Nijhoff/Wolters Plantyn.

Harmes, Ingeborg (2006). Shall, zullen en sollen: een contrastieve analyse. In: Matthias Hüning, Ulrike Vogl, Ton van der Wouden \& Arie Verhagen (red.), Nederlands tussen Duits en Engels. Leiden: SNL, pp. 243-258. 
Hertog, C. H. den (1903). Nederlandsche Spraakkunst. Handleiding ten dienste van aanstaande (taal)onderwijzers, volume III. Amsterdam: W. Versluys (Tweede druk).

Hilpert, Martin (2008). Germanic future constructions: A usage-based approach to language change. Amsterdam/Philadelphia: John Benjamins.

Janssen, Theo A.J.M. (1983). Het temporele systeem van het Nederlands: twee tijden en drie tijdscomposities. Glot 6, 45-104.

Janssen, Theo A.J.M. (1988). Tense and temporal composition in Dutch. In V. Ehrich \& H. Vater (red.), Temporalsemantik. Tübingen: Max Niemeyer Verlag, pp. 96-128.

Janssen, Theo A.J.M. (1989a). Die Hilfverben ndl. zullen und dt. werden: modal oder temporal? In: Werner Abraham \& Theo Janssen (red.), Tempus - Aspekt - Modus. Die lexikalischen and grammatischen Formen in den germanischen Sprachen. Tübingen: Niemeyer, pp. 65-84.

Janssen, Theo A.J.M. (1989b). Tempus: interpretatie en betekenis. De Nieuwe Taalgids 82, 305-329.

Kirsner, Robert S. (1969). The role of zullen in the grammar of Modern Standard Dutch. Lingua 24, $101-154$.

Kirsner, Robert S. (2012). 2005: Arie Verhagen, Constructiegrammatica en 'usage based' taalkunde. Internationale Neerlandistiek 50 (jubileumnummer 1963-2012), 133-135.

Kollewijn, Roeland A. (1892). Het systeem van de tijden der werkwoorden. Taal en letteren 2, 141-147.

Langacker, Ronald W. (2008). Cognitive Grammar: A basic introduction. Oxford: Oxford University Press.

Langacker, Ronald W. (2011). The English present: Temporal coincidence vs. epistemic immediacy. In: Adeline Patard \& Frank Brisard (red.), Cognitive approaches to tense, aspect, and epistemic modality. Amsterdam/Philadelphia: John Benjamins, pp. 45-86.

Luif, Jan (1994). In verband met de zin. Inleiding in de Nederlandse spraakkunst. Amsterdam: Amsterdam University Press.

Narrog, Heiko (2012). Modality, subjectivity, and semantic change. Oxford: Oxford University Press.

Olmen, Daniël van, Tanja Mortelmans \& Johan van der Auwera (2009). Grammaticalization and subjectification of the future: the case of English, Dutch and German. In: Wieslaw Oleksy \& Piotr Stalmaszczyk (red.), Cognitive approaches to language and linguistic data: studies in honor of Berbara Lewandowska-Tomaszczyk, Frankfurt am Main: Peter Lang, pp. 285-306.

Reichenbach, Hans (1947). Elements of symbolic logic. New York: the Free Press; London: Collier-Macmillan.

Roels, Linda, Tanja Mortelmans \& Johan van der Auwera (2007). Dutch equivalents of the German past conjunctive: zou + infinitive and the modal preterit. In: In: Louis de Saussure, Jacques Moeschler \& Geneveva Puskas (red.), Tense, mood and aspect. Theoretical and descriptive issues (Cahiers Chronos 17), Amsterdam/New York: Rodopi, pp. 177-196.

Rooij, J. de (1985). De toekomst in het Nederlands I. Over het uitdrukken van de toekomende tijd in standaardtaal en dialect. Taal en Tongval 37, 96-123.

Rooij, J. de (1986). De toekomst in het Nederlands II. Over het uitdrukken van de toekomende tijd in standaardtaal en dialect. Taal en Tongval 38, 5-32. 
Rijpma, E. \& F. Schuringa, (1968). Nederlandse Spraakkunst. Groningen: J.B. Wolters $\left(21^{\mathrm{e}}\right.$ druk, bewerkt door Jan van Bakel).

Santen, Ariane van (z.j.). Traditionele zinsontleding. Syllabus, Opleiding Nederlandse Taalen Cultuur, Universiteit Leiden.

Sweetser, Eve (1990). From etymology to pragmatics. Cambridge: Cambridge University Press.

Te Winkel, Lammert A. (1866). Over de wijzen en tijden der werkwoorden. De Taalgids 8, 66-75.

Verkuyl, Henk J. (2008). Binary Tense, volume 187 of CSLI Lecture Notes. Stanford, CA: CSLI Publications.

Verkuyl, Henk J. (2012). De binaire kracht van Te Winkels tempussysteem. Nederlandse Taalkunde 17, 1-25.

Weiland, P. (1805). Nederduitsche Spraakkunst. Amsterdam.

WNT. M. de Vries, L.A. te Winkel e.a. (red.; 1882-1998). Woordenboek der Nederlandsche Taal. 's-Gravenhage/Leiden: Martinus Nijhoff/Brill. 